\title{
PRÓBA OCENY ZARZUTÓW NIEPEENEJ IMPLEMENTACJI POLSKIEGO PRAWA OCHRONY PRZYRODY NA PRZYKŁADZIE PYTANIA PREJUDYCJALNEGO SĄDU REJONOWEGO W KOŚCIANIE* (CZĘŚĆ I)
}

\section{AN ATTEMPT TO ASSESS CLAIMS OF INCOMPLETE IMPLEMENTATION OF POLISH ENVIRONMENTAL LAW BASED ON THE EXAMPLE OF A PREJUDICIAL QUESTION OF THE DISTRICT COURT IN KOŚCIANA}

\section{(PART I)}

\section{STRESZCZENIE}

W obecnym systemie prawnym skuteczna ochrona elementów przyrody w państwach członkowskich uzależniona jest w dużej mierze

Autor jest członkiem Regionalnej Rady Ochrony Przyrody działającej przy Regionalnym Dyrektorze Ochrony Środowiska w Szczecinie; Uniwersytet Szczeciński, Wydział Prawa i Administracji, Katedra Prawa Ochrony Środowiska.

** Niniejszy artykuł jest poszerzeniem referatu wygłoszonego przez autora na II Ogólnopolskiej Konferencji „Prawo Ochrony Przyrody a procesy inwestycyjne", która odbywał się pod patronatem Ministerstwa Środowiska oraz Ministerstwa Infrastruktury na Wydziale Prawa i Administracji Uniwersytetu Łódzkiego w dniach 21-22 września 2009 r. 
od poprawnej implementacji przepisów unijnych. Dotyczy to zwłaszcza reglamentacji handlu gatunkami chronionymi. Pytanie prejudycjalne Sądu Rejonowego w Kościanie ujawnia luki prawne w polskiej ustawie o ochronie przyrody, które przesądzają o konieczności jej pilnej nowelizacji. Istniejący stan prawny zagraża istnieniu populacji niektórych gatunków zwierząt chronionych i może rodzić po stronie nasze państwa odpowiedzialność za naruszenie norm prawa unijnego. $\mathrm{W}$ tym kontekście autor formuje konkretne wnioski de lege ferenda co do budowy tekstu prawnego, jak i stawia tezy odnośnie do korzystania przez sądy krajowe z instytucji pytań prejudycjalnych.

\section{Słowa kluczowe}

Prawo ochrony przyrody, prawo unijne, handel gatunkami chronionymi, implementacja, luka prawna.

\section{ABSTRACT}

In the present law system, an effective protection of the nature elements in the EU members states is dependent, to a large degree, on the right implementation of EU Nature Legislation. It especially concerns the rationing of trade of protected species. The prejudicial question of the District Court in Kościana reveals gaps in polish law regulations relating to nature protection that indicates the necessity of its prompt alteration. The present law condition may put in danger some of the protected species and may cause the state to be responsible for violating some of statues of the EU law. In this context the author of the paper formulates specific conclusions de lege ferenda in regards to the law framework as well as poses thesis statements concerning the use of prejudicial question by the state courts.

\section{Keywords}

EU Nature Legislation, EU Law, Trade of Protected Species, Implementation, Legal gap. 


\section{WSTĘP $P^{* * *}$}

Celem nadrzędnym, jaki postawił sobie autor niniejszej publikacji, jest usystematyzowanie pewnej kategorii luk prawnych, które mogą pojawić się przy stosowaniu polskiej ustawy o ochronie przyrody ${ }^{1} \mathrm{w}$ przypadku reglamentowanego obrotu określonymi gatunkami zwierząt z perspektywy regulacji prawa unijnego. Przeprowadzony proces badawczy ma za zdanie również zdefiniować konkretne postulaty de lege ferenda $\mathrm{w}$ tym przedmiocie. W ocenie autora kilka fragmentarycznych nowelizacji ustawy o ochronie przyrody ${ }^{2}$ przeprowadzonych na przestrzeni kilku ubiegłych lat nie rozwiązuje wielu pojawiających się na gruncie prawa unijnego problemów interpretacyjnych związanych z jej stosowaniem, co tym samym przesądza o konieczności nowego i kompleksowego spojrzenia na kwestię ochrony przyrody w Polsce. Tezę taką potwierdzają chociażby wyroki wydane przez Trybunał Sprawiedliwości, w których zarzuca się Polsce kolejne naruszenia norm unijnych ${ }^{3}$, mających swoją genezę w tej właśnie ustawie. Zostały one wydane na podstawie skarg kierowanych do Trybunału przez Komisję Europejską i co

**** Tytułem wstępu za wszelką okazaną pomoc i życzliwość chciałbym podziękować Pani Agnieszce Olszewskiej SSR w Kościanie orzekającej w sprawie Tomasza R. oraz aplikantowi radcowskiemu Panu Tomaszowi Trych.

1 Ustawa z dnia 16 kwietnia 2004 r. o ochronie przyrody (tekst jedn. Dz.U. 2009, Nr 151, poz. 1220 z późn. zm.).

2 Od strony poruszanych w dalszej części aspektów prawnych chodzi tu zwłaszcza o ustawą z dnia 3 października 2008 r. o zmianie ustawy o ochronie przyrody oraz niektórych innych ustaw (Dz.U. 2008, Nr 201, poz. 1237), która ustaliła obecnie obowiązującą treść art. 64 ust. 1 ustawy o ochronie przyrody.

3 Przykładem takim jest wyrok Trybunału z dnia 15 marca 2012 r. - Komisja Europejska przeciwko Rzeczpospolitej Polskiej - sprawa C-46/01 (Dz.U. UE C 133,05.05.2012, s. 9). Trybunał uznał, że Rzeczpospolita Polska dokonała nieprawidłowej transpozycji do polskiego prawa warunków wprowadzania odstępstw od zakazów zawiązanych z ochroną gatunkową ptaków i zwierząt, jakie zawarte są w art. 16 ust. 1 dyrektywy Rady 92/43/EWG z dnia 21 maja 1992 r. w sprawie ochrony siedlisk przyrodniczych oraz dzikiej fauny i flory (Dz.Urz. UE L 206, 22.07.1992, s. 7-50; tekst w języku polskim opublikowany w Dz.Urz. UE Polskie wydanie specjalne 2004, rozdz. 15, t. 2, s. 102-145). 
jest interesujące, ukazują one, iż niezbędność podjęcia inicjatyw nowelizacyjnych dotyczy nie tylko samej ustawy, ale także wielu aktów wykonawczych wydanych w oparciu o delegacje zawarte w jej treści. Omówienie ich przekracza jednak zakres tematyczny niniejszego opracowania. Nie mniej jednak, na nich podstawie można sformułować generalne twierdzenie, że nieprawidłowy zakres normowania przepisu rangi ustawowej, co do zbioru wszystkich możliwych i potencjalnych, nakazanych lub zakazanych zachowań, przekłada się wprost proporcjonalnie na nieprawidłowe jego uszczegółowienie w przepisach wykonawczych. Wskazana konstrukcja teoretyczna znalazła swoje odzwierciedlenie w wyroku Trybunału Sprawiedliwości z dnia 26 stycznia 2012 r. w sprawie C-192/11 Komisja Europejska przeciwko Polsce, gdzie Trybunał orzekł o nieprawidłowej transpozycji do prawa polskiego art. 1, art. 5 oraz art. 9 ust. 1 i 2 dyrektywy Parlamentu. Europejskiego i Rady 2009/147/WE ${ }^{4}$ (tzw. dyrektywy ptasiej) poprzez nie objęcie ochroną wszystkich gatunków dzikich ptaków występujących naturalnie w stanie dzikim na europejskim terytorium państw członkowskich, a także nieprawidłowe określenie warunków ustanowienia odstępstw od zakazów ustanowionych w tej dyrektywie ${ }^{5}$. Trybunału w uzasadnieniu przedmiotowego orzeczenia oceniając stopień naruszenia przez Polskę obowiązków ogólnych ustanowionych $\mathrm{w}$ przepisach ustawy o ochronie przyrody, dowodził ich istnienia przeprowadzając między innymi proces subsumcji norm umiejscowionych w przepisach wykonawczych ${ }^{6}$.

Trzeba pamiętać, że obowiązki wynikające z norm środowiskowych ujmowane są w orzecznictwie Trybunału dość re-

4 Dyrektywa Parlamentu Europejskiego i Rady 2009/147/WE z dnia 30 listopada 2009 r. w sprawie ochrony dzikiego ptactwa (wersja ujednolicona) (Dz.Urz. UE L 20, 26.01.2010, s. 7-25).

5 Wyrok Trybunału z dnia 26 stycznia 2012 r. Komisja Europejska przeciwko Rzeczpospolitej Polskiej - sprawa C-192/11 (Dz.Urz. UE C 73, 10.03.2012, s. 6).

6 Chodzi tutaj o przepisy uchylonego z dniem 23 listopada 2011 r. Rozporządzenia Ministra Środowiska z dnia 28 września 2004 r. w sprawie gatunków dziko występujących zwierząt objętych ochroną (Dz.U. 2004, Nr 220, poz. 2237). 
strykcyjnie. Przy orzekaniu bez znaczenia pozostaje na przykład wina państwa w popełnieniu naruszenia, czy też brak szkody po stronie środowiska7 ${ }^{7}$ Odpowiedzialność istnieje tak długo, jak możliwe jest przypisanie naruszenia danego obowiązku, a okolicznością wyłączającą taką odpowiedzialność nie stanowią trudności wewnętrzne państwa w postaci problemów ekonomicznych czy też praktycznych ${ }^{8}$, jak też podjęcie przez niego procesu nowelizacji spornych przepisów $\mathrm{w}$ fazie postępowania przed Trybunałem ${ }^{9}$. Przesłanki odpowiedzialności, zwłaszcza w ochronie gatunkowej, badane są często przez Trybunał

7 Przyjmuje się, że z uwagi na to, że odpowiedzialność za wyrządzenie szkód gatunkom chronionym lub siedliskom przyrodniczym wyraźnie nawiązuje do zawinienia, a contrario odpowiedzialność za wyrządzenie szkód co do zasady znajduje zastosowanie niezależnie od zawinienia. Surowy system odpowiedzialności niezależnej od winy odpowiada szczególnym zagrożeniom dla środowiska, które należy wziąć pod uwagę przy wykonywaniu danej działalności wiążącej się ze swej natury z takim ryzykiem - por. pkt. 92 Opinii Rzecznika Generalnego Juliane Kokott z dnia 22 października 2009 r. w sprawie C-378/08 (wniosek o wydanie orzeczenia w trybie prejudycjalnym złożony przez Tribunale Amministrativo Regionale per la Sicilia (Włochy) w dniu 21 sierpnia 2008 r. — ERG Raffinerie Mediterranee SpA i inni przeciwko Ministero dello Sviluppo Economico i inni (Dz.Urz. UE C 301, 22.11.2008, s. 14).

8 Szerzej K Boiret, A. Boiret, Odpowiedzialność państw członkowskich UE w dziedzinie ochrony środowiska naturalnego, w: A. Kozłowski, B. Mielnik (red.), Odpowiedzialność międzynarodowa, jako element międzynarodowego porzadku prawnego, „Acta Uniwersitatis Wratislaviensis”, nr 3140, Wydawnictwo Uniwersytetu Wrocławskiego 2009, s. 141-168.

9 Tezę taką w doktrynie prawa unijnego potwierdzają zarzuty ujęte w postępowaniu zainicjowanym skargą Komisji Europejskiej przeciwko Rzeczpospolitej Polskiej - sprawa C - 48/12 (Dz.Urz. UE C 80, 17.03.2012, s. 13). Naruszenie dotyczy terminu transpozycji do naszego sytemu prawnego dyrektywy 2008/50/WE Parlamentu Europejskiego i Rady z dnia 21 maja 2008 r. w sprawie jakości powietrza i czystszego powietrza dla Europy (dalej jako: dyrektywa CAFE) (Dz.Urz. UE L 152, 11.06.2008, s. 1-44). W skardze Komisja stwierdza, że „zgodnie z art. 33 ust. 1 dyrektywy CAFE Rzeczpospolita Polska miała przyjąć i wprowadzić w życie krajowe przepisy prawne niezbędne do wykonania dyrektywy do 11 czerwca 2010 r. Rzeczpospolita Polska nie przyjęła do polskiego porządku prawnego ani nie wprowadziła w życie wszystkich niezbędnych przepisów. Opracowanie założeń projektu ustawy o zmianie ustawy - Prawo ochrony środowiska oraz niektórych innych ustaw przez Ministerstwo Środowiska nie stanowi spełnienia obowiązku przewidzianego w art. 33 ust. 1 dyrektywy". 
w kontekście transgranicznym, co może implikować wspólną odpowiedzialność państw członkowskich za dane naruszenie. Tak szerokie ujmowanie odpowiedzialności podyktowane jest naturalnym procesem przemieszczaniem się pewnych gatunków w obrębie Wspólnoty i w związku z tym koniecznością zapewniania im pełnej ochrony na wszystkich, nawet potencjalnych, miejscach ich występowania ${ }^{10}$.

Analizując orzeczenia merytoryczne kończące postępowania przed Trybunałem, warto zauważyć, że samo skierowanie skargi nie przesądza jeszcze o jej zasadności i odpowiedzialności danego państwa członkowskiego, lecz sądzę, że stanowi to dla ustawodawcy krajowego pewien sygnał, iż dany akt prawny wymaga analizy pod kątem jego spójności z prawem unijnym w ramach dyrektyw wykładni systemowej. Jednym $\mathrm{z}$ fundamentalnych postulatów tej właśnie wykładni jest uzyskanie wewnętrznej integralności systemu wyinterpretowanych z tekstów prawnych norm oraz odrzucenie, jako niedopuszczalnej takiej interpretacji tekstu prawnego, w wyniku której nastąpiłaby sytuacja, iż formułowane $\mathrm{w}$ nim normy są $\mathrm{w}$ pewnym zakresie zastosowania między sobą niezgodne. Niezgodność formalna norm to stan prawny, w którym normy mają choćby częściowo wspólny zakres zastosowania, odnośnie do tych samych adresatów i stanów faktycznych, jednakże ich zakres normowania jest ze sobą niezgodny. Niezgodność ta nie ma charakteru pozornego, gdy zawarte w nich nakazy nie mogą być równocześnie zrealizowane ${ }^{11}$. Spójność szczególnie trudno zachować w sytuacji, gdy redakcja tekstu prawnego ustawy o ochronie przyrody w niektórych przypadkach jest wewnętrznie rozbieżna czy niekonsekwentna, na co wskazuje część badaczy prawa ${ }^{12}$. Należy

10 Por. Z. Brodecki, T. Koncewicz, P. Kupczyk, M. Pchałek, Ochrona przyrody przed Europejskim Trybunałem Sprawiedliwości. Komentarz", w: Ogólnopolskie Towarzystwo Ochrony Ptaków, Marki 2010, a także F. Jacobs, The Role of the European Court of Justice in the Protection of the Environment, w: Oxford Journals, Journals of Environmental Law 2006, nr 18(2), s. 185-205.

11 Por. Z. Ziembiński, Logika praktyczna, Warszawa 2009, s. 240 i nast.

12 Por. J. Solon, O potrzebie rewolucyjnych zmian $w$ prawie ochrony przyrody, w: D. Kopeć, N. Ratajczak (red.), Prawo ochrony przyrody - stan obecny, problemy, perspektywy, „Towarzystwo Przyrodników Ziemi Łódzkiej”, Łódź 
uwzględnić założenie, że niezgodność między normami prawa wewnętrznego stanowi nie tylko naruszenie zasady pewności prawa, ale także może wprowadzać w błąd organy odpowiedzialne za wykonanie danych przepisów co do szczegółowych warunków stosowania określonego systemu ochrony w danej gałęzi prawa ${ }^{13}$. Skuteczne funkcjonowanie sytemu ochrony prawnej określonych gatunków, zwłaszcza przy ochronie ex situ, jest podstawowym gwarantem zachowania danej populacji, dlatego tak ważne jest, aby od strony formalnej, przepisy budujące taką strukturę były w pełni wykonalne.

Prowadzone $\mathrm{w}$ momencie pisania niniejszej publikacji działania legislacyjne, a mam na myśli ustawę z dnia 13 lipca 2012 r. o zmianie ustawy o ochronie przyrody oraz niektórych innych ustaw - Druk sejmowy nr 441, są odpowiedzią na cytowane powyżej wyroki Trybunału Sprawiedliwości przeciwko Polsce i mają za zadanie wyeliminować luki prawne związane z nieprawidłową transpozycją prawa unijnego, a także ustrzec nasz kraj przed grożącymi z tego tytułu sankcjami ${ }^{14}$. Analizując treść przepisów ustawy, jak i uzasadnienie projektu, stwierdzam, że ustawodawca dokonując po raz kolejny, w trybie pilnym nowelizację, ograniczył ją do niezbędnego minimum, nie uwzględniając $\mathrm{w}$ niej innych koniecznych zmian podyktowanych na przykład wyrokiem zapadłym w sprawie będącej tematem przedmiotowego artykułu ${ }^{15}$.

2008, s. 21-27 oraz M. Gwiazdowicz, System ochrony przyrody w Polsce - regulacje prawne i instytucje. Problemy systemu ochrony przyrody w: E. Karpowicz (red.), Ochrona przyrody. Studia Biura Analiz Sejmowych Kancelarii Sejmu, Warszawa 2008, s. 10-11.

13 Por. pkt 137 Wyrok Trybunału z dnia 12 lipca 2007 r. Komisja Europejska przeciwko Republice Austrii - sprawa C-507/04 (Dz.U. UE C 211, 08.09.2007, s. 2-3).

14 Por. Opinia na temat rządowego projektu ustawy o zmianie ustawy o ochronie przyrody oraz ustawy - Prawo łowieckie (druk nr 441), 12 czerwca 2012 r., s. 1-2 oraz Kancelaria Sejmu - Biuro Komisji Sejmowych, „Pełny zapis z przebiegu posiedzenia Komisji Ochrony Środowiska Zasobów Naturalnych i Leśnictwa (Nr 28) z dnia 28 czerwca 2012 r.”, s. 4 i nast., w: http:// www.sejm.gov.pl/Sejm7.nsf/PrzebiegProc.xsp?nr=441.

15 Por. ustawa z dnia 13 lipca 2012 r. o zmianie ustawy o ochronie przyrody oraz niektórych innych ustaw (Dz.U. 2012 Nr 985). 
Powinno się podkreślić, że analiza pytania prejudycjalnego skierowanego przez Sąd Rejonowy w Kościanie ${ }^{16}$ ma nie tylko swój wymiar prawny, ale także i historyczny, gdyż w judykaturze polskiego prawa ochrony środowiska jest to pierwsze pytanie prejudycjalne sądu polskiego z zakresu tej właśnie gałęzi prawa. Stanowi to dowód na często podnoszone w literaturze przedmiotu twierdzenie wzrostu wagi kwestii środowiskowych w innych dziedzinach prawa, zwłaszcza tych formułujących sankcje za jego naruszenie. Należy pamiętać, że środowisko naturalne $\mathrm{w}$ Polsce jest przedmiotem ochrony konstytucyjnej ${ }^{17}$, a więc jego ochrona, jako dobra wspólnego, stanowi jedno z naczelnych zadań, do których powołane jest nie tylko społeczeństwo, ale i samo państwo poprzez odpowiednie kształtowanie obowiązującego porządku prawnego ${ }^{18}$. Ranga tego obowiązku nie pozwala na jego wybiórcze stosowanie czy na tolerowanie stanu, w którym niektóre działania lub zaniechania podmiotów prawa, naruszające wprawdzie przepisy prawa unijnego, w prawie krajowym nie są zagrożoną odpowiednią sankcją karną. Jest to ważne tym bardziej, że w obecnym czasie zauważa się wzrost znaczenia odpowiedzialności karnej za naruszenie norm środowiskowych nie tylko w prawie europejskim, ale i międzynarodowym ${ }^{19}$. Instrumentem unijnym realizującym

16 Wniosek o wydanie orzeczenia w trybie prejudycjalnym złożony przez Sąd Rejonowy w Kościanie (Rzeczpospolita Polska) w dniu 24 lipca 2008 r. Postępowanie karne przeciwko Tomaszowi R. - sprawa C-344/08 (Dz.Urz. UE C 272, 25.10.2008, s. 10).

17 A. Krzywoń, Konstytucja RP a środowisko „Państwo i Prawo”, sierpień 2012, nr 8, s. 3-17.

18 Art. 74 pkt 2 Konstytucji Rzeczpospolitej Polskiej z dnia 2 kwietnia 1997 r. (Dz.U. 1997 Nr 78, poz. 483 z późn. zm.) zobowiązuje władz publiczne do ochrony środowiska, a art. 86 wprowadza obowiązek dbałości o środowisko w stosunku do każdego obywatela; Szerzej problematykę tą omawia A. Milke, Zarys konstytucyjnych podstaw ochrony środowiska, „Studia Iuridica??????????", t. 50 L/2009, s. 95-100, a także B. Rakoczy, Ograniczenie praw i wolności jednostki ze względu na ochronę środowiska w Konstytucji Rzeczypospolitej Polskiej, Toruń 2006.

19 Przeglądu zasad przestrzegania oraz mechanizmów kontroli i egzekwowania umów międzynarodowych $\mathrm{z}$ dziedziny ochrony środowiska dokonuje M. Bar, J. Jendrośka, Umowy międzynarodowe EKG ONZ z dziedziny ochrony środowiska oraz zasady ich przestrzegania, Wrocław 2004, s. 43-76. 
postulat zaostrzenia tej właśnie odpowiedzialności jest dyrektywa w sprawie ochrony środowiska poprzez prawo karne ${ }^{20}$ (dalej jako: dyrektywa karna). W jej preambule wyraźnie akcentuje się, że obowiązujący system sankcji jest niewystarczający do zapewnienia pełnego przestrzegania przepisów dotyczących ochrony środowiska, a za jego intensyfikacją przemawia fakt, iż sankcje karne mają inny oddźwięk społeczny i są bardziej jaskrawą oznaką potępienia, określonego nagannego postępowania podmiotu, aniżeli sankcje administracyjne czy mechanizm odszkodowawczy działający w ramach prawa cywilnego ${ }^{21}$. Główną dyrektywą wymiaru kary ma być prewencja generalna skierowana na kształtowanie świadomości prawnej społeczeństwa $\mathrm{w}$ zakresie przestrzegania norm środowiskowych, poprzez wzmocnienie odpowiedzialności karnej za szczególnie poważne naruszenia przepisów prawa unijnego. Słowniczek dyrektywy w art. 2 pkt b lit. ii nakazuje stosować jej postanowienia do chronionych gatunków dzikiej flory i fauny, poprzez którą rozumie się między innymi gatunki wymienione w załączniku A i B rozporządzenia Rady 338/97 w sprawie ochrony gatunków dzikiej fauny i flory w drodze regulacji handlu nimi ${ }^{22}$ (dalej jako: rozporządzenie 338/97). Rozporządzenie to ma, jak się przekonamy później, kluczowe znaczenie dla poparcia tezy postawionej przez autora w temacie niniejszego studium. Przestępstwem wedle kwalifikacji dyrektywy karnej pozostają czyny dokonane bezprawnie i umyślnie lub będące skutkiem przynajmniej rażącego niedbalstwa. Od strony przedmiotowej, zgodnie z art. 3 lit. g, czyn zabroniony ma polegać na handlu okazami chronionych gatunków dzikiej fauny lub flory, ich częściami lub pochodny-

20 Dyrektywa Parlamentu Europejskiego i Rady 2008/99/WE z dnia 19 listopada 2008 r. w sprawie ochrony środowiska przez prawo karne (Dz.Urz. UE L 328, 06.12.2008, s. 28-37).

21 Por. M.G. Faure, K. Svatikova, Criminal or Administrative Law to Protect the Environment? Evidence from Western Europe, Oxford Journals, „Journals of Environmental Law" 2012, nr 24(2), s. 253-286.

22 Rozporządzenie Rady (WE) Nr 338/97 z dnia 9 grudnia 1996 r. w sprawie ochrony gatunków dzikiej fauny i flory w drodze regulacji handlu nimi (Dz.Urz. UE L 61, 03.03.1997, s. 1-69; tekst w języku polskim opublikowany w Dz.Urz. UE Polskie wydanie specjalne 2004, rozdz. 15, t. 3, s. 136-150). 
mi, z wyjątkiem przypadków, gdy postępowanie takie dotyczy nieznacznej liczby takich okazów i ma nieznaczny wpływ na zachowanie gatunków. Na etapie procesu legislacyjnego dyrektywy karnej zwracano uwagę na bardzo istotną kwestię, która wiąże się pośrednio z głównym wątkiem niniejszej publikacji, to jest niedopuszczeniem do tego, by z transpozycji wynikły znaczne rozbieżności między prawodawstwem różnych państw członkowskich - „nielogiczna byłaby, bowiem sytuacja, że dany czyn byłby karalny w jednym państwie członkowskim, a w innym nie"23. Ma to zapewnić podobne traktowanie poważnych przestępstw przeciwko środowisku we wszystkich państwach członkowskich oraz uniemożliwić przestępcom wyciągnięcie korzyści z różnic istniejących pomiędzy przepisami obowiązującymi w poszczególnych państwach ${ }^{24}$.

Reminiscencjom obowiązku transpozycji do prawa polskiego treść dyrektywy karnej jest art. 128a ustawy o ochronie przyrody, który stanowi, że kto handluje okazami gatunku podlegającego ochronie na podstawie przepisów, o których mowa w art. 61 ust. 1 (ustawy o ochronie przyrody - mój przyp.), w liczbie większej niż nieznaczna, w takich warunkach lub w taki sposób, że ma to wpływ na zachowanie właściwego stanu ochrony gatunku, podlega karze pozbawienia wolności od 3 miesięcy do lat 5. Jeżeli sprawca czynu określonego w ust. 1 działa nieumyślnie, podlega karze ograniczenia wolności albo pozbawienia wolności do lat $2^{25}$. Na bazie powyższej regulacji, a także wspomnianego powyżej art. 3 lit. g dyrektywy kar-

23 Tak pkt 3.12 Opinii Europejskiego Komitetu Ekonomiczno-Społecznego w sprawie wniosku dotyczącego dyrektywy Parlamentu Europejskiego i Rady w sprawie ochrony środowiska poprzez prawo karne (Dz.Urz. UE C 10, 15.01.2008, s. 50).

24 Por. Wniosek dotyczący dyrektywy Parlamentu Europejskiego i Rady w sprawie ochrony środowiska poprzez prawo karne (przedstawiony przez Komisję), KOM(2007), 51 wersja ostateczna, Bruksela 09.02.2007 r., s. 6, w: http://eur-lex.europa.eu/LexUriServ/LexUriServ.do?uri=COM:2007:0051:FIN:PL:PDF.

25 Przepis ten został dodany do ustawy na mocy art. 3 pkt 2 ustawy z dnia 25 marca 2011 r. o zmianie ustawy - Kodeks karny oraz niektórych innych ustaw (Dz.U. 2011, Nr 94, poz. 549) - zgodnie z uzasadnieniem projektu ustawy - Druk sejmowy nr 3755 - ma ona na celu wdrożenie do systemu pra- 
nej, a contrario należałoby postawić sobie pytanie, jaka liczba okazów danych gatunków jest liczbą mniejszą niż nieznaczna według ustawodawcy, która nie wpłynie na zachwianie stanu ochrony, a tym samym nie będzie zagrożona odpowiedzialnością karną? Należy domniemywać, że skoro brak jest definicji tego pojęcia zarówno w dyrektywie karnej, jak i w słowniczku ustawy o ochronie przyrody (art. 5), to pojęcie to trzeba zakwalifikować jako nieostre, a jego ocena została pozostawiona swobodnej ocenie sędziego krajowego podczas przebiegu subsumcji norm przy rozstrzyganiu konkretnej sprawy procesowej. W pełni popieram stanowisko literatury, że wymóg zapewnienia jednolitej i autonomicznej interpretacji prawa unijnego odnosi się również do pojęć niedookreślonych, pozostawienie zaś państwom członkowskim pełnej swobody wykładni pojęć niedookreślonych zawartych $\mathrm{w}$ dyrektywach doprowadziłoby do paraliżu procesu harmonizacji ${ }^{26}$.

Doktryna odnosząc się do rozwój polskiego prawa karnego, jednoznacznie wskazuje na wzrost ilości przestępstw przeciwko środowisku ${ }^{27}$. Słusznie znawcy przedmiotu zauważają, że „tendencja penalizowania określonych zachowań wynika nie tylko z faktu gruntującej się świadomości ekologicznej oraz potrzeby ochrony środowiska jako wartości uniwersalnej, jako reakcja na postępującą jego degradację, ale także z tego, że zakres samej ochrony środowiska jest coraz szerszy ${ }^{28}$. W literaturze ocena odpowiedzialności karnej i jej skuteczności wobec potencjalnych sprawców nie jest jednoznacznie oceniana. W dziedzinie tej panuje duża rozbieżność pomiędzy oczekiwa-

wa polskiego postanowień dyrektywy w sprawie ochrony środowiska poprzez prawo karne w: http://orka.sejm.gov.pl/proc6.nsf/opisy/3755.htm.

26 Zagadnienie funkcjonowania zwrotów niedookreślonych $\mathrm{w}$ systemie prawa, w tym także prawa wspólnotowego podejmuje E. Łętowska, Interpretacja a subsumcja zwrotów niedookreślonych i nieostrych, „Państwo i Prawo” 2011, z. 7-8, s. 17-29.

27 Koncepcje prawa karnego środowiska omawia W. Radecki, Ochrona środowiska $w$ polskim prawie karnym", cz. I: Pojęcie i zakres prawa karnego środowiska, „Monitor Prawniczy” 1997, nr 12.

28 Tak L. Mering, Środowisko, jako przedmiot ochrony karnoprawnej, „Gdańskie Studia Prawnicze”, t. 14, 2005, s. 742. 
niami teoretycznymi a efektywnością funkcjonujących w obrocie norm prawnych ${ }^{29}$. W mojej ocenie do trudności związanych z egzekwowaniem norm środowiskowych na arenie międzynarodowej może pośrednio przyczyniać się fakt braku definicji środowiska w międzynarodowym prawie publicznym, jak też brak wyspecjalizowanej organizacji światowej czuwające w wymiarze globalnym nad jego przestrzeganiem. Popieram stanowisko niektórych z badaczy prawa, którzy podnoszą, iż „stworzenie i zamieszczenie w prawie konwencyjnym „kompleksowej” definicji środowiska mogłoby się przyczynić do większej efektywności międzynarodowego prawa środowiska ${ }^{30 "}$.

Zdaniem autora, aby wykładnia rysujących się problemów była pełna, trzeba oprzeć ją na podstawowych definicjach i założeniach, którymi kieruje się w obrocie dana gałąź prawa. Zadania związane z ochrona przyrody powiązane są systemowo z ochroną elementów środowiska jako całości. Na taką klasyfikację wskazuje już sama definicja legalna pojęcia ochrony środowiska funkcjonująca $\mathrm{w}$ prawie polskim ${ }^{31}$, poprzez którą rozumie się podjęcie lub zaniechanie działań, umożliwiające zachowanie lub przywracanie równowagi przyrodniczej32. Trafnie przyjmuje się, że „właściwy stan elementów przyrodniczych powinien być oceniany z punktu widzenia ich funkcji w środowisku, w kontekście zachowania lub przywrócenia jego równowagi przyrodniczej33. Prawo ochrony środowiska w swej treści, a ściślej w art. 127 zawiera wskazówki interpretacyjne, określające podstawowe standardy i formy ochrony zasobów przyrody, których doprecyzowanie zostało powierzone ustawom szcze-

29 Por. J. Ciechanowicz-McLean, Penalizacja prawa ochrony środowiska, „Gdańskie Studia Prawnicze”, t. 14,2008, s. 9-20.

30 Tak J. Ciechanowicz-McLean, Międzynarodowe prawo środowiska wobec problemów globalnych, „Gdańskie Studia Prawnicze”, t. 17, 2007, s. 523.

31 Szerzej M. Roliński, Ewolucja pojęcia prawnego „środowisko” $i$ „ochrona środowiska”, „Studia Iuridica Lublinensia”, Lublin 2005, s. 158-165.

32 Art. 3 pkt. 13 ustawy z dnia 27 kwietnia 2001 r. Prawo ochrony środowiska (tekst jedn. Dz.U. 2008, Nr 25, poz. 150 z późn. zm.).

33 Szerzej W. Skarżyńska, M. Bojarski, M. Bar, J. Boć, K. Nowacki, J. Jerzmański, M. Górski, J. Jendrośka (red. nauk.), E. Kaleta-Jagiełło, J. Rotko, T. Tatomir, A. Lipiński, „Ustawa - Prawo ochrony środowiska. Komentarz”, w: Centrum Prawa Ekologicznego, Wrocław 2001, s. 1045. 
gółowym. Zakres ochrony został oparty zarówno na funkcjach konserwatorskich, jak i funkcji prewencyjnej przepisów prawa, co przekłada się z jednej strony na konieczność zachowywania cennych ekosystemów, różnorodności biologicznej i utrzymania równowagi ekologicznej, z drugiej zaś na szeroko rozumiane zapobieganie negatywnemu oddziaływaniu na te właśnie elementy przyrodnicze ${ }^{34}$. Wskazane założenia odpowiadają wprost ustawowej definicji ochrona przyrody, zgodnie z którą ochrona polega na zachowaniu, zrównoważonym użytkowaniu oraz odnawianiu zasobów, tworów i składników przyrody ${ }^{35}$. Z punktu widzenia zagadnień przedstawionych powyżej warto zauważyć, że samo pojęcie ochrony na gruncie doktryny prawa nie zostało dość precyzyjne sformułowane. Powstające rozbieżności wynikają z wielości terminologii anglojęzycznej używanej dla określenia działań związanych z ochroną oraz braku konsekwencji $\mathrm{w}$ posługiwaniu się nimi w różnych aktach i dokumentach międzynarodowych oraz z odmiennych stanowisk prezentowanych przez przedstawicieli nauki prawa ${ }^{36}$. Analiza postępowania karnego prowadzonego przeciwko Tomaszowi R. potwierdzi, że w niektórych przypadkach istnienie luk prawnych może legalizować niektóre formy naruszeń norm środowiskowych, co z kolei może prowadzić w dłuższej perspektywie czasu do zachwiania istniejącej równowagi przyrodniczej. Stan taki nie jest pożądany, gdyż faktycznie może doprowadzić do zubożenia występowania danego gatunku w ekosystemie, a w dłuższej perspektywie czasu, do utraty różnorodności biologicznej. Powiązanie gatunków żyjących w każdym ekosystemie jest na tyle silne, iż wyginięcie lub zachwianie populacji jednego z nich, na przykład na skutek niekontrolowanego handlu, może powodować, iż dany ekosystem nie będzie w stanie wypełniać swoich

34 Por. J. Ciechanowicz-McLean, Z. Bukowski, B. Rakoczy, „Prawo ochrony środowiska - komentarz", Wydawnictwa Prawnicze LexisNexis, Warszawa 2008, s. 264-265.

35 Art. 2 ust. 1 ustawy z dnia 16 kwietnia 2004 r. o ochronie przyrody (tekst jedn. Dz.U. 2009, Nr 151, poz. 1220 z późn. zm.).

36 Kwestię tę porusza M. Górski (red.), J. S. Kierzkowska, „Prawo ochrony środowiska", w: Wyższa Szkoła Informatyki i Nauk Społeczno-Prawnych w Bydgoszczy, Bydgoszcz 2006, s. 454 i następ. 
funkcji. Degradacja taka w dłuższym okresie czasu wpłynie wprost propocjonalnie na straty gospodarcze, a także społeczne w regionie, w którym funkcjonuje dany ekosystem. W krajach Unii Europejskiej problem ten został już zauważony od dawna i odpowiedzią na jego zagrożenia ma być wdrożenie unijnej strategii ochrony bioróżnorodności na okres do $2020 \mathrm{r}^{37} \mathrm{~W}$ swoim komunikacie Komisja zauważa, że statystycznie w Unii Europejskiej jedynie 17\% siedlisk i gatunków oraz 11\% kluczowych ekosystemów utrzymanych jest we właściwym stanie ochrony na mocy obowiązującego prawodawstwa ${ }^{38}$, pomimo działań podjętych w zakresie zwalczania utraty różnorodności biologicznej, które zostały podjęte w ubiegłej strategii, której okres programowania upłynął w $2010 \mathrm{r}^{39}$ Nowa strategia obejmuje sześć wzajemnie się wspierających i współzależnych celów, tj. ochronę przyrody, utrzymanie i wzmocnienie ekosytemów i ich funkcji, zapewnienie zrównoważonego rozwoju rolnictwa, leśnictwa i rybołówstwa, zwalczanie inwazji gatunków obcych, restytucje i zieloną infrastrukturę oraz zwiększenie wkładu Unii Europejskiej w ogólnoświatową różnorodność biologiczną ${ }^{40}$. Ważnym elementem wzmacniającym realizację powyższych celów będą właściwie dystrybuowane instrumenty finansowe, zarówno nowe, jak i te przewidziane $\mathrm{w}$ ramach przyszłej polityki spójności. Konieczne jest również zaznaczenie, że Unia

37 Komunikat Komisji do Parlamentu Europejskiego, Rady, Europejskiego Komitetu Społeczno- Ekonomicznego, Komitetu Regionów, „Nasze ubezpieczenie na życie i nasz kapitał naturalny - unijna strategia ochrony różnorodności biologicznej na okres do 2020 r.”, KOM (2011)244 wersja ostateczna, Bruksela dnia 3.5.2011,http://ec.europa.eu/environment/nature/biodiversity/comm2006/pdf/2020/comm_2011_244/1_PL_ACT_part1_v2.pdf.

38 Szerzej European Environment Ägency, EU 2010 biodiversity baseline, EEA Technical report No 12/2010, w: http://www.eea.europa.eu/publications/eu-2010-biodiversity-baseline/.

39 Komunikat Komisji, „Zatrzymanie procesu utraty różnorodności biologicznej do roku 2010 i w przyszłości - Utrzymanie usług ekosystemowych na rzecz dobrobytu człowieka", KOM (2006) 216 wersja ostateczna, Bruksela 22.05.2006, w: http://eurlex.europa.eu/LexUriServ/LexUriServ.do?uri=COM:2006:0216:FIN:PL:PDF.

40 Szerzej A. Erechemla, Strategia ochrony bioróżnorodności - instrumenty prawne”, „Prawo i Środowisko”, 30 czerwca 2012 r., nr 2 (70)11, s. 50-54. 
będzie bardziej wspomagała obecne wysiłki w celu poprawy współpracy i synergii oraz ustanowienia wspólnych priorytetów pomiędzy konwencjami związanymi z różnorodnością biologiczną ${ }^{41}$.

\section{ZAŁOŻENIA IMPLEMENTACJI ORAZ ZARYS UNIJNEGO PRAWA OCHRONY PRZYRODY}

Odniesienie się do kwestii związanych z procesem implementacji unijnego prawa ochrony przyrody jest konieczne, gdyż porównanie jego założeń z regulacjami prawnymi, które były podstawą orzekania w sprawie rozpoznawanej przez Sąd Rejonowy w Kościanie, uwidocznią nam luki prawne, które ideę takiej właśnie implementacji wypaczają. Z jednej strony pojawienie się luk w procesie stosowania prawa bezpośrednio przekłada się na zachwianie stanu środowiska, a w konsekwencji na wystąpienie w nim szkód. Z drugiej strony należy wziąć pod uwagę hipotezę, że każdy proces zachodzący w sferze prawa państw członkowskich, aby był prawidłowy i adekwatny do intencji ustawodawcy unijnego, poza spełnieniem wymogów czysto legislacyjnych, musi odbywać się zgodnie z zasadami ogólnymi danej gałęzi prawa. Wśród zasad można dokonywać różnych klasyfikacji ze względu na przedmiotom czy też cel ochrony. Sądzę jednak, że z uwagi właśnie na cele ochrony prawnej, działania podejmowane w środowisku przyrodniczym, muszą nade wszystko odgrywać rolę prewencyjną, tym bardziej, jeśli dotyczą one niekontrolowanego obrotu gatunkami zagrożonymi wyginięciem, co nastąpiło w sprawie, która stanowi ramy tematyczne niniejszej publikacji. Z perspektywy sytemu prawa zasada prewencji jest ważnym gwarantem zrównoważonego rozwoju, a więc idei zrównoważonego korzystania z zasobów

41 Por. pkt 3 Opinii Europejskiego Komitetu Ekonomiczno-Społecznego w sprawie siódmego programu działań w zakresie środowiska i dalszych działań w następstwie szóstego programu działań w zakresie środowiska (opinia rozpoznawcza) (Dz.Urz. UE C 191, 29.06.2012, s. 3-5). 
środowiska ${ }^{42}$. Zrównoważony rozwój obejmuje nie tylko kwestie środowiskowe, ale ma również swój wymiar gospodarczy i społeczny. Dominująca obecnie idea zintegrowanego podejścia do kwestii środowiskowych narzuca, aby wszelkie działania prewencyjne oparte były na regułach ostrożności ${ }^{43}$ i aby dokonywano je zawsze $\mathrm{w}$ perspektywie globalnej ${ }^{44}$. Zasada prewencji to jeden z podstawowych wyznaczników działań środowiskowych, dlatego też słusznie przypisuje się jej rangę zasad naczelnej

42 Ciekawą analizę problematyki zrównoważonego rozwoju w orzecznictwie Europejskiego Trybunał Sprawiedliwości podejmuje Z. Bukowski, Zrównoważony rozwój w systemie prawa,Toruń 2009, s. 324-343.

43 „Zasada ostrożności nie jest zdefiniowana w prawie wspólnotowym. W orzecznictwie jest ona analizowana w zakresie, w którym przy niepewności co do wystąpienia ryzyka mogą zostać podjęte interwencyjne środki ochrony, bez konieczności oczekiwania na pełne wykazanie zaistnienia ryzyka i jego ciężaru. Decydującym elementem jest z tego względu brak naukowej pewności co do oceny ryzyka. Jednakże w konkretnych przypadkach interwencje związane ze środkami ochrony powinny być współmierne względem przypuszczalnego ryzyka. Komisja stwierdza w swym komunikacie o stosowaniu zasady ostrożności, że określenie stopnia ryzyka „akceptowalnego” dla społeczeństwa stanowi decyzję obciążoną dużą odpowiedzialnością polityczną. Odpowiedzialności tej można uczynić zadość jedynie wówczas, gdy przed podjęciem decyzji niepewność nauki zostanie zredukowana do minimum poprzez użycie najlepszych dostępnych środków naukowych" - pkt 100 Opinii Rzecznika Generalnego Juliane Kokott z dnia 29 stycznia 2004 r. w sprawie C-127/02 (wniosek Raad van State o wydanie orzeczenia w trybie prejudycjalnym): Landelijke Vereniging tot Behoud van de Waddenzee, Nederlandse Vereniging tot Bescherming van Vogels przeciwko Staatssecretaris van Landbouw, Natuurbeheer en Visserij (Dz.Urz. UE C 262, 23.10.2004, s. 2). $\mathrm{Na}$ aspekty praktyczne powiązane z funkcjonowaniem zasady ostrożności w orzecznictwie Trybunału Sprawiedliwości zwraca uwagę M. Michalak, Rola zasady przezorności ( $w$ definiowaniu pojęć wspólnotowego porządku prawnego w orzecznictwie Europejskiego Trybunału Sprawiedliwości), „Prawo i Środowisko", nr 1(61)/10, s. 96-101. Autorka trafnie zauważa, że zasad przezorności w orzecznictwie Trybunału, oddziałuje głównie na interpretację środowiskowych przepisów wspólnotowych odnoszących się do pojęć o charakterze technicznym.

${ }_{44} \mathrm{Z}$ punktu widzenia prawa międzynarodowego, ochrona środowiska, jako dobra wspólnego o charakterze ponadnarodowym, może w pewnych przypadkach wymagać także ograniczenia fundamentalnych zasad konstytucyjnych - por. K. Klenowska, Zasada suwerenności terytorialnej w ochronie środowiska, „Przegląd Prawa Ochrony Środowiska” 2009, nr 1, s. 11-25. 
w całym systemie prawa ochrony środowiska ${ }^{45}$. Zasada ta znalazła swój wyraz w art. 191 ust. 1 Traktatu o funkcjonowaniu Unii Europejskiej - dalej jako TFUE (dawny art. 174 Traktatu ustanawiającego Wspólnotę Europejską), który stanowi: „Polityka Wspólnot w dziedzinie ochrony środowiska naturalnego opiera się [...] na zasadach działania zapobiegawczego"46, zaś w prawie polskim wypełnia ją treść art. 6 ust. 1 prawa ochrony środowiska poprzez sformułowanie, iż „Kto podejmuje działalność mogącą negatywnie oddziaływać na środowisko, jest obowiązany do zapobiegania temu oddziaływaniu". Charakter prawny zasady prewencji polega na założeniu, że lepiej zapobiegać negatywnemu oddziaływaniu na środowisko, niż następnie środowisko naprawiać i przywracać do stanu poprzedniego. Granice podmiotowe, jak i przedmiotowe tej zasady są ustanowione bardzo szeroko, gdyż obowiązki z niej wynikające mogą dotyczyć w zasadzie każdego podmiotu, a prowadzona przez niego działalność, obejmuje nie tylko działalność gospodarczą, lecz każde działanie lub zaniechanie mogące negatywnie oddziaływać na środowisko ${ }^{47}$. Doktryna słusznie zauważa, że „odkładanie interwencji do momentu, kiedy szkody się ujawnią się w środowisku, może spowodować sytuację, w której opanowanie jej skutków będzie wymagało podjęcia bardziej kosztownych działań od tych, które można było zrealizować wcześniej, stosując zasadę prewencji"48. Wspomnieć jedynie należy, że unijnym aktem prawnym formalnie wcielającym w życie wskazane przesłanki jest dyrektywa w sprawie odpowiedzialności za środowisko w odniesieniu do zapobiegania i zaradzania szkodom wyrządzonym środowisku naturalnemu ${ }^{49}$, natomiast jej transpozycja

45 Por. M. Górski, Ochrona środowiska jako zadanie administracji publicznej, Łódź 1992, s. 115.

46 Traktatu o funkcjonowaniu Unii Europejskiej (Wersja skonsolidowana) (Dz.Urz. UE C 326, 26.10.2012, s. 132).

47 Por. E. Iwanek-Chachaj, Zasada prewencji i przezorności w prawie ochrony środowiska, „Studia Iuridica Lublinensia”, Lublin 2008, s. 137-147.

48 P. Korzeniewski, Zasady prawne ochrony środowiska, Łódź 2010, s. 370.

49 Dyrektywy 2004/35/WE Parlamentu Europejskiego i Rady z 21 kwietnia 2004 r. w sprawie odpowiedzialności za środowisko w odniesieniu do zapobiegania i zaradzania szkodom wyrządzonym środowisku naturalnemu 
do polskiego sytemu nastąpiła na podstawie ustawy o zapobieganiu szkodom w środowisku i ich naprawie ${ }^{50}$.

W polskim orzecznictwie administracyjnym, odnoszącym się do ochrony przyrody ochrony przyrody, zasada prewencji stanowi częstokroć podbudowę do interpretacji przepisów prawa wewnętrznego w duchu prounijnej wykładni, co ma za zadanie zapewnić jego pełną skuteczność we wszystkich aspektach stosowania prawa ${ }^{51}$. Niektórzy z badaczy prawa zauważyli, że oddziaływanie porządków prawnych różnych państw członkowskich w obszarze stosowania prawa unijnego, ich zasad lub normy ogólnych, doprowadziło nawet do wykształcenia się regionalnego, „europejskiego" międzynarodowego prawa administracyjnego ${ }^{52}$. Ponadto dostrzegli oni, iż wykładnia prounijna z reguły bazuje na dyrektywach systemowych lub celowościowych, a nie wyłącznie na metodzie językowej, co jest tożsame z metodami przyjętymi w rodzimej kulturze prawnej i praktyce sądowoadministracyjnej ${ }^{53}$. Obszar takiej wykładni mieści w sobie wszelkie akty prawa, w tym niewiążące akty normatywne i to nie tylko te wydane w celu wykonania prawa Unii, ale i cały

(Dz.Urz. UE L 143, 30.04.2004, s. 56-75; tekst w języku polskim opublikowany w Dz.Urz. UE Polskie wydanie specjalne 2004, rozdz. 15, t. 8, s. 357-375), zmieniona Dyrektywą 2006/21/WE Parlamentu Europejskiego i Rady z dnia 15 marca 2006 r. w sprawie gospodarowania odpadami pochodzącymi z przemysłu wydobywczego oraz zmieniająca dyrektywę 2004/35/WE (Dz.Urz. UE L 102, 11.04.2006, s. 15-34) oraz Dyrektywą Parlamentu Europejskiego i Rady 2009/31/WE z dnia 23 kwietnia 2009 r. w sprawie geologicznego składowania dwutlenku węgla oraz zmieniająca dyrektywę Rady 85/337/ EWG, Euratom, dyrektywy Parlamentu Europejskiego i Rady 2000/60/WE, 2001/80/WE, 2004/35/WE, 2006/12/WE, 2008/1/WE i rozporządzenie (WE) nr 1013/2006 (Dz.Urz. UE L 140, 05.06.2009, s. 114-135).

50 Ustawa z dnia 13 kwietnia 2007 r. o zapobieganiu szkodom w środowisku i ich naprawie (Dz.U. 2007, Nr 75, poz. 493 z późn. zm.).

51 Por. uzasadnienie wyroku NSA z dnia 24 czerwca 2010 r., sygn. akt II OSK 961/09, niepubl.

52 Wskazuje na to M. Zieliński, O pojęciu międzynarodowego prawa administracyjnego, „Państwo i Prawo” 2008, z. 9, s. 18.

53 Szerzej K. Łuczak, Metody wykładni prawa krajowego, a wykładnia zgodna z prawem unijnym ( $w$ orzecznictwie sądów administracyjnych), „Państwo i Prawo" 2011, z. 1, s. 59-73. 
dorobek ustanowiony przed datą akcesji ${ }^{54}$. Według dogmatyki prawniczej proces prounijnej egzegezy przepisów przez sąd krajowy jest obowiązkiem, który aktualizuje się w momencie wystąpienia niezgodności pomiędzy prawem unijnym a prawem danego państwa członkowskiego, która to kolizja nie może zostać usunięta poprzez zastosowanie zasady pierwszeństwa prawa unijnego. Granice takiej wykładni nie są jednak nieograniczone i można z niej korzystać dopóty, dopóki nie prowadzi ona do zaprzeczenia prawa krajowego lub jego odrzucenia, a więc w konsekwencji do wykładni contra legem ${ }^{55}$. Szczególnie zagrożenie takie istnieje w procedurze karnej, gdyż doktryna podkreśla, że „wykładnia prowspólnotowa [teraz prounijna - mój przypis] może powodować pogorszenie sytuacji prawnej jednostki, jednakże wyłącznie w zakresie odpowiedzialności cywilnoprawnej lub obowiązków cywilnoprawnych, natomiast nie może ona zwiększać odpowiedzialności karnej jednostkii" ${ }^{50}$. Teza ta nabiera szczególnego znaczenia, jeśli weźmiemy pod uwagę fakt, że to właśnie pytanie prejudycjalne stanowiące osnowę niniejszej publikacji, od strony formalnej zostało skierowane przez Sąd Rejonowy w Kościanie w postępowaniu karnym toczącym się przeciwko Tomaszowi R. i dotyczyło w zasadzie kwestii dopuszczalności odpowiedzialności karnej, która na bazie przepisów ustawy o ochronie przyrody nie istniała, natomiast zgodnie z wytycznymi przepisów unijnych odpowiedzialność taka winna być ustanowiona przy tego rodzaju czynach i zagrożona wymierną sankcją karną. Orzecznictwo Trybunału szukając korzeni w zasadzie pewności i nieretroaktywności prawa, stoi na stanowisku, że akt prawa wspólnotowego nie może samo-

54 Szerzej S. Biernat, Wykładnia prawa krajowego zgodnie z prawem wspólnotowym, w: C. Mik (red.), Implementacja prawa integracji europejskiej $w$ krajowych porządkach prawnych, Toruń 1998, s. 132 i nast.

55 Wykładnia prounijna powinna być stosowana w prawie karnym dopóki nie doprowadzi ona do wykładni sprzecznej z wolą prawodawcy krajowego, tj. wykładni contra legem - Tak G. Krzysztofiuk, Obowiązek prounijnej interpretacji prawa karnego, „Studia Iuridica”, t. 46, „Z Zagadnień Prawa Karnego” 2006, s. 209-222.

56 K. Kowalik-Bańczyk, Prowspólnotowa wykładnia prawa polskiego, „Europejski Przegląd Sądowy" 2005, nr 12, s. 9-18. 
dzielnie i niezależnie od implementujących go norm prawnych nadawać skutku ustanawiającego odpowiedzialność karną osób, która uprzednio nie istniała, lub też skutku zwiększającego tę odpowiedzialność w stosunku do osób działających w sposób sprzeczny z tym aktem, niezgodnie z jego postanowieniami ${ }^{57}$. Dokonując prounijnej wykładni prawa karnego, właściwy podmiot jest $\mathrm{w}$ swoim działaniu ograniczony ogólnymi zasadami prawa, które stanowią część zasad prawa wspólnotowego, a w szczególności zasadami nulla crimen sine lege (nie ma przestępstwa bez ustawy) oraz nulla poena sine lege (nie ma kary bez ustawy $)^{58}$. Praktyczne odzwierciedlenie tych zasad może jednak napotykać na pewne trudności semantyczne ${ }^{59}$, biorąc pod uwagę cechy znaczeniowe języka, w którym formułowane są przepisy i definicje $\mathrm{w}$ prawie unijnym, a to, $\mathrm{w}$ jakiej formie zostaną one transponowane do prawa krajowego. Czy takie błędy leksykalne pojawiające się w przepisach ustawy o ochrony przyrody były i są podstawowym wyznacznikiem niepełnej implementacji, na to pytanie spróbujemy sobie odpowiedzieć w dalszej części artykułu.

Jestem zdania, że aby zapewnić właściwą skutecznością działań ochronnych w stosunku do gatunków zagrożonych wyginięciem na poziomie europejskim, przepisy je regulujące w poszczególnych państwach członkowskich muszą odznaczać się pełną kompletnością zakresu normowania, a więc w konsekwencji winny one nie naruszać jednej z podstawowych zasad prawa unijnego, to jest zasady jego efektywności (efet utile) ${ }^{60}$,

57 Tak pkt. 13 i 14 Wyroku Trybunału z dnia 8 października 1987 r. postępowanie karne przeciwko Kolpinghuis Nijmegen BV. wniosek o wydanie orzeczenia w trybie prejudycjalnym: Arrondissementsrechtbank Arnhem - Niderlandy - sprawa C-80/86 (Dz.U. UE C 294, 05.11.1987, s. 5).

58 Por. uwagi A. Arnull, Having your Cake and Eating it Ruled Out, "European Law Review" 1988, s. 42-45.

59 Teoretyczne rozważanie na temat zasady nulla crimen sine lege podjął: J. Wyrembak, Zasada nulla crimen sine lege a wykładnia prawa (ze szczególnym uwzględnieniem pozycji metody językowej), „Przegląd Sądowy” styczeń 2009, LexisNexis, s. 85-94.

60 Zasad skuteczności prawa wspólnotowego (efet utile) to jedna z ważniejszych zasad definiujących cele prawa wspólnotowego, która została wypracowana na przestrzeni lat w orzecznictwie Trybunału Sprawiedliwości - 
której korzenie sięgają prawa rzymskiego, i maksymy benignius leges interpretandae sunt, quo voluntas earum conservetur (ustawy są właściwiej interpretowane, gdy zachowuje się ich ducha). Reguła ta jest następstwem obowiązku dostosowania prawa wewnętrznego państw członkowskich do wymagań unijnych i spełnieniem zasady lojalnej współpracy wyrażonej w art. 4 ust. 3 TUE ${ }^{61}$. Harmonizacja krajowych porządków prawnych $\mathrm{w}$ duchu nadania ich przepisom skuteczności odnosi się do podejmowania działań na trzech płaszczyznach. Pierwsza to przyjęcie lub zmiana przepisów krajowych w tym także zasad i procedur (tzw. transpozycja prawa). Druga płaszczyzna, określana jako „implementacja”, związana jest z zapewnieniem warunków dla realizacji przepisów poprzez między innymi powołanie organów odpowiedzialnych za ich wdrażanie oraz zagwarantowanie źródeł ich finansowania. Trzecim elementem zapewniającym właściwą skuteczność przepisów w ramach ich harmonizacji jest wprowadzenie procedur zabezpieczających poprzez adekwatny do działań naruszających system kontroli i kar ${ }^{62}$. Z perspektywy ochrony elementów przyrodniczych, skuteczność oznacza, iż przepisy danego systemu prawa spełniają zarówno funkcje prewencyjne, a w przypadku naruszenia norm w nich zawartych także i funkcje karne, w tym znaczeniu, iż zapewniają one w praktyce to, że cel, jakim jest ochrona gatunkowa, jest w całości osiągnięty. Brak skuteczności, a więc stan faktyczny, gdy w ramach danego stosunku prawnego korzystanie z prawa unijnego staje się $\mathrm{w}$ praktyce niemożliwe lub nadmiernie utrudnione ${ }^{63}$, może powodować nie tylko wypaczenie

szerzej R. Stefanicki, Fundamenty efektywności prawa wspólnotowego, „Studia Prawnicze" 2004, nr 3, s. 1-53.

${ }^{61}$ Traktatu o Unii Europejskiej (Wersja skonsolidowana) (Dz.Urz. UE C 326, 26.10.2012, s. 18).

${ }_{62}$ Por. uwagi M. Górski, Gospodarowanie odpadami w świetle wymagań prawa wspólnotowego i polskiego prawa wewnętrznego, Poznań 2005, s. 25-27.

${ }_{63}$ „Trybunał orzekał już, że każdy przypadek, w którym powstaje pytanie, czy krajowe przepisy proceduralne czynią niemożliwym lub zbyt utrudnionym stosowanie prawa wspólnotowego, należy rozpatrywać z uwzględnieniem miejsca danego przepisu w całości procedury, jej przebiegu i jej cech szczególnych, przed poszczególnymi sądami krajowymi. W tej perspektywie należy uwzględnić, w razie potrzeby, zasady znajdujące się u podstaw krajo- 
podstawowych idei przyświecających ustawodawcy unijnemu w procesie stanowienia danej gałęzi prawa, ale może być także przesłanką do formułowania wobec danego państwa członkowskiego zarzutu niepełnej implementacji w ramach procedury kontrolnej, której wykonywanie zostało powierzone Komisji Europejskiej, jako Strażnice Traktatów ${ }^{64}$. To właśnie Komisja Europejska monitorując corocznie stosowanie prawa w państwach członkowskich, ustaliła, w oparciu o wszczynane postępowania, że proces zarządzania procesem transpozycji poza Włochami, najdłużej w Europie trwa właśnie w Polsce ${ }^{65}$. Co jest niepokojącą tendencją, w Unii największe opóźnienia dotyczą właśnie transpozycji przepisów z zakresu ochrony środowiska, gdzie terminy są systematycznie niedotrzymywane.

Implementacja, jako kolejny krok we wdrażaniu przepisów unijnych, ze swego założenia nie ogranicza się do wydawania wykonawczych aktów prawnych, lecz obejmuje również wszelkie działania związane z zapewnieniem warunków dla efektyw-

wego systemu prawnego, takie jak ochrona prawa do obrony, zasady pewności prawa i prawidłowego przebiegu postępowania" - tak pkt 39 wyroku Trybunału z dnia 6 października 2009 r. (wniosek o wydanie orzeczenia w trybie prejudycjalnym złożony przez Juzgado de Primera Instancia n o 4 de Bilbao Hiszpania) - Asturcom Telecomunicaciones SL przeciwko Cristinie Rodríguez Nogueirze - sprawa C 40/08 (Dz.Urz. UE C 282, 21.11.2009, s. 7-8).

64 Uchybienia tego rodzaju klasyfikowane są jako naruszenia zobowiązań ciążących na danym państwie na mocy Traktatu Europejskiego, co jest podstawą do skierowania przez Komisję skargi do TS - zgodnie z art. 226 TWE. Analiza danych statystycznych z ostatnich lat uwidacznia pewną dość ciekawą tendencję. W przypadku około 68\% skarg postępowanie zostaje zamknięte przed pierwszym formalnym etapem postępowania w sprawie. W około 84\% przypadków postępowania, których podstawą jest skarga, zamykane są przed etapem wydania uzasadnionej opinii, a w około 94\% przypadków przed wydaniem orzeczenia przez Trybunał Sprawiedliwości. Pod koniec 2008 r. Komisja była w trakcie rozpatrywania ogółem ponad 3400 skarg i spraw dotyczących uchybień traktatowych - Komisja Europejska: „26 Sprawozdanie roczne z kontroli stosowania prawa wspólnotowego (za rok 2008) z dnia 15.12.2009 r., KOM(2009) 675 wersja ostateczna.

65 Komisja Europejska: „28. Sprawozdanie roczne z kontroli sprawowania prawa (za rok 2010), KOM(2011) 588 wersja ostateczna, Bruksela dnia 29.09.2011, s. 5 . http://ec.europa.eu/eu_law/docs/docs_infringements/annual_report_28/ com_2011_588_pl.pdf. 
nego działania przyjętych norm generalnych, co oznacza powiązanie jej na poziomie krajowym ze stosowaniem i kontrolą przestrzegania prawa. Jeśli więc przepis krajowy zbudowany jest od strony reguł językowych w ten sposób, że w niektórych przypadkach może on zawężać stosowanie norm unijnych tylko do określonego kręgu adresatów, to tym samym w każdym przypadku jego stosowania nie gwarantuje on optymalnej efektywności prawa unijnego, a co za tym idzie, nie możemy mówić wówczas, iż taka implementacja krajowa jest pełna i prawidłowa. Niewłaściwa implementacja to nie tylko wybiórcze uwzględnienie przepisów danego aktu unijnego, ale również niespójne z prawem unijnym odczytywanie ich treści i celu, jakiemu powinny one służyć ${ }^{66}$. Konsekwencjami takiej właśnie implementacji może być jak w przypadku sprawy, która toczyła się przed Sądem Rejonowym w Kościanie, niebezpieczeństwo niezgodnej z prawem unijnym depenalizacji, niektórych czynów czy określonej grupy sprawców. Należy pamiętać, że to właśnie na państwie członkowskim spoczywa główny ciężar zapewnienia, aby każdy akt prawa wspólnotowego był należycie stosowany w jego porządku prawnym, co w kontekście pytania prejudycjalnego Sądu Rejonowego w Kościanie oznacza także gwarancję odpowiedniego egzekwowania jego naruszeń.

Reasumując niektóre z podniesionych powyżej aspektów prawnoteoretycznych implementacji prawa unijnego, trzeba powiedzieć, że wzmocnienie i poprawa wdrażania jego przepisów są obecnie uznawane za priorytetowy cel europejskiej polityki środowiskowej, której przyszłe ramy mają być przygotowane w ramach siódmego unijnego programu działania na rzecz ochrony środowiska. Opóźnione lub nieodpowiednie wdrażanie przepisów powoduje wiele negatywnych skutków. Może w ostatecznym rezultacie powodować namacalne szkody dla środowiska naturalnego, jak i zdrowia ludzkiego, generować brak pewności prawnej i stawiać pod znakiem zapytania równe szanse na

66 Por. Z. Bukowski, Wybrane zagadnienia związane z nieprawidłowa implementacja wspólnotowego prawa ochrony środowiska do prawa polskiego, w: J. Jędrośka, M. Bar (red.), Wspólnotowe prawo ochrony środowiska i jego implementacja $w$ Polsce trzy lata po akcesji, Wrocław 2008, s. 87-99. 
jednolitym rynku europejskim. Finansowe koszty niewdrożenia obowiązujących przepisów prawnych są zasadniczo szacowane w całej Unii na około 50 mld euro rocznie ${ }^{67}$.

Analizując od strony systemowej przepisy wchodzące w skład unijnego prawa ochrony przyrody, ogólnie można sklasyfikować je, jako normy prawne zgrupowane w dwóch rodzajach aktów, którymi są rozporządzenia oraz dyrektywy ${ }^{68}$. Teoretycznie rzecz ujmując, unijny porządek prawnym przyjął zasadę, że przepisy, których ranga jest na tyle istotna, że wymagają pilnego i ścisłego wdrożenia w państwach członkowskich, umiejscawiane są w rozporządzeniach (ang. regulation, fr. réglement, niem. die Verordnung). Założenie to wypływa $\mathrm{z}$ istoty rozporządzenia, które ma zasięg ogólny, obowiązuje co do wszystkich swoich elementów i nadaje się do bezpośredniego stosowania ${ }^{69}$. Dlatego też rozporządzenie staje się z dniem wejścia w życie częścią porządków prawnych państw członkowskich jako akt prawny powszechnie obowiązujący. Należy zatem zdawać sobie sprawę, że adresatami praw i obowiązków zawartych w rozporządzeniach, jako aktów prawa wtórnego o charakterze abstrakcyjnym, są nie tylko państwa członkowskie, ale również jednostki, czyli osoby fizyczne i prawne. W tym miejscu warto zadać sobie pytanie, czy skoro z samej definicji rozporządzenia wynika, iż jest

67 Szerzej Komunikat Komisji do Parlamentu Europejskiego, Rady, Europejskiego Komitetu Ekonomiczno-Społecznego i Komitetu Regionów, „Lepsze wykorzystanie potencjału środków ochrony środowiska UE: budowanie zaufania poprzez większą wiedzę i lepszą zdolność reakcji, KOM(2012) 95 final, Bruksela dnia 07.03.2012, s. 3 i nast., http://eur-lex.europa.eu/LexUriServ/ LexUriServ.do?uri=COM:2012:0095:FIN:PL:PDF

68 Chodzi tutaj zwłaszcza o dyrektywę Rady 92/43/EWG z dnia 21 maja 1992 r. w sprawie ochrony siedlisk przyrodniczych oraz dzikiej fauny i flory (Dz.Urz. UE L 206, 22.07.1992, s. 7-50; tekst w języku polskim opublikowany w Dz.Urz. UE Polskie wydanie specjalne 2004, rozdz. 15, t. 02, s. 102-145), dyrektywę Rady 2009/147/WE z dnia 30 listopada 2009 r. w sprawie ochrony dzikiego ptactwa (wersja ujednolicona) (Dz.Urz. UE L 20, 26.01.2010, s. 7-25) czy też dyrektywę Rady 1999/22/WE z dnia 29 marca 1999 r. dotyczącą trzymania dzikich zwierząt w ogrodach zoologicznych (Dz.Urz. UE L 94, 09.04.1999, s. 24-26; tekst w języku polskim opublikowany w Dz.Urz. UE Polskie wydanie specjalne 2004, rozdz. 15, t. 4, s. 140-142).

69 Art. 288 (dawny art. 249 TWE) - Wersja skonsolidowana Traktatu o funkcjonowaniu Unii Europejskiej (Dz.Urz. UE C 83, 30.03.2010, s. 171). 
on bezpośrednio stosowane w każdym państwie członkowskim to, w jakiej materii możemy mówić o jego implementacji i czy $\mathrm{w}$ ogóle stosowanie takiego pojęcia $\mathrm{z}$ punktu widzenia teorii prawa jest dopuszczalne? Literatura przedmiotu bada raczej kwestie związane z wdrażaniem do krajowego porządku prawnego dyrektyw, aniżeli rozporządzeń, to jednak niektórzy z badaczy prawa dostrzegają również zagadnienie implementacji rozporządzeńn ${ }^{70}$. Implementacja w tym znaczeniu według nich odbywa się w dwóch płaszczyznach jako implementacja unijna i krajowa. Implementacja unijna skupia się na stanowieniu aktów wykonawczych, które stworzą odpowiednie warunki do uruchomienia norm i procedur przewidzianych w rozporządzeniu, a częstokroć także powołują one do życia organy czuwające nad ich stosowaniem. Implementacja krajowa polega natomiast na przyjmowaniu przez państwa członkowskie norm i działań implementujących, co w konsekwencji przekłada się nierzadko na obowiązki sprawozdawcze w stosunku do organów unijnych.

Ramy konstrukcyjne niniejszej publikacji nakazują nam zająć się przede wszystkim rozporządzeniem w sprawie ochrony gatunków dzikiej fauny i flory w drodze regulacji handlu nimi ${ }^{71}$, o którym to wspominałem już na wstępie, oraz ewentualnie przepisami wykonawczymi wydanymi na jego bazie, o ile mogą one odgrywać pewną rolę przy wykładni uregulowań polskiej ustawy o ochronie przyrody, które były brane przy orzekaniu $\mathrm{w}$ postępowaniu prowadzonym przeciwko Tomaszowi R. przez sąd I, jak i II instancji. Oceniając w dalszej części publikacji zarzut niepełnej implementacji tego rozporządzenia

70 Por. C. Mik, „Europejskie prawo wspólnotowe - Zagadnienia teorii i praktyki”, w: Wydawnictwo C.H. Beck, Warszawa 2000, s. 664-665.

71 W chwili obecnej Komisja Europejska ze względu na dużą ilość nowelizacji rozporządzenia (WE) 338/97, prowadzi prace mające na celu jego przekształcenie, które w zamierzeniach poprzez doprecyzowanie niektórych regulacji ma zapewnić jasność i przejrzystość w ich stosowaniu przez wszystkie państwa członkowskie - Komisja Europejska: „Wniosek - Rozporządzenie Parlamentu Europejskiego i Rady w sprawie ochrony dzikiej fauny i flory w drodze regulacji handlu nimi (przekształcenie), COM(2012) 403 final, 2012/0196 (COD), Bruksela dnia 19.07.2012, http://eur-lex.europa.eu/LexUriServ/LexUriServ.do?uri=COM:2012:0403:FIN:PL:PDF. 
w naszym systemie prawnym, nieodzownym wydaje się odniesienie do utrwalonych poglądów nauki prawa, zakorzenionych w orzecznictwie Trybunału Luksemburskiego. Stanowisko to bazuje na tezie, że „państwa członkowskie nie mogą ani podejmować krajowych środków prawnych, ani też zezwalać krajowym organom o kompetencjach prawodawczych na podejmowanie przepisów, które godzić będą we wspólnotowy [teraz unijny mój przypis] charakter rozporządzeń oraz wywoływane przez rozporządzenia skutki prawne dla ich adresatów. Na mocy zobowiązań wynikających z TWE [teraz Traktatu o funkcjonowaniu Unii Europejskiej - mój przypis] na państwach członkowskich ciąży obowiązek niepodejmowania środków naruszających bezpośrednie stosowanie rozporządzeń, a ścisłe jego przestrzeganie jest nieodzownym warunkiem jednoczesnego i jednolitego stosowania rozporządzeń w całej Wspólnocie [teraz Unii - mój przypis] ${ }^{72 "}$.

Charakteryzując pokrótce strukturę unijnego rozporządzenia w sprawie ochrony gatunków dzikiej fauny i flory w drodze regulacji handlu nimi, stwierdzić należy, że opiera się ono na systemie reglamentacji obrotu handlowego określonymi gatunkami roślin i zwierząt, tak by nie doprowadzić do ich wyginięcia w naturalnych ekosystemach i zarazem poprawić poziom ich ochrony. Okazy gatunków pogrupowane zostały w czterech załącznikach od litery „A” do litery „D”, w zależności od skali stopnia zagrożenia, gdzie załącznik A obejmuje okazy gatunków, które są najbardziej narażone na ujemne skutki wynikające $\mathrm{z}$ handlu nimi $\mathrm{w}$ aspekcie międzynarodowym ${ }^{73}$. Konstrukcja

72 A. Łazowski, Stosowanie rozporządzeń wspólnotowych na płaszczyźnie wewnętrznej państw członkowskich, w: Prawo Unii Europejskiej w wewnętrznym porządku prawnym państw członkowskich, Warszawa 2004, s. 91, a także por. M. A. Górska, A. Legat, Stosowanie przepisów rozporządzeń wspólnotowych w świetle orzecznictwa Naczelnego Sądu Administracyjnego „Przegląd Sądowy” 2009, nr 7-8, s. 32-42.

73 Aktualne wykazy gatunków roślin i zwierząt objętych załącznikami A, B, C i D zostały zmienione lub uzupełnione o nowe na mocy Rozporządzenia Komisji (UE) Nr 1158/2012 z dnia 27 listopada 2012 r. zmieniające rozporządzenie Rady (WE) nr 338/97 w sprawie ochrony gatunków dzikiej fauny i flory w drodze regulacji handlu nimi (Dz.Urz. UE L 339, 12.12.2012, s. 1-77). 
prawna systemu ochrony zbudowana jest z zezwoleń przywozowych (art. 5 rozporządzenia) oraz zezwoleń na wywóz lub świadectw powrotnego wywozu (art. 6 rozporządzenia). Wprowadzanie i wywóz odbywa się na terenie Unii w wyznaczonych urzędach celnych, a do monitorowania przestrzegania przepisów i dochodzenia ich naruszeń zobowiązane są na mocy rozporządzenia wszystkie państwa członkowskie. Ważnym elementem całej struktury działań ochrony jest także wymiana informacji oraz stosowanie w praktyce, w oparciu o wytyczne rozporządzenia, jednolitych na terenie całej Unii sankcji za jego naruszenie. Uregulowania zawierają również normy, które przewidują pewne odstępstwa dotyczące okazów gatunków urodzonych i wychodowanych w niewoli lub sztucznie rozmnożonych (art. 7 rozporządzenia) i wykładnią tych właśnie przepisów zajmiemy się szczegółowo w dalszej części publikacji z racji treści pytania prejudycjalnego Sądu Rejonowego w Kościanie. Ustawodawca wprowadził także $\mathrm{w}$ rozporządzeniu postanowienia odnoszące się do przewozu żywych okazów gatunków (art. 9 rozporządzenia) oraz kontroli prowadzenia działalności handlowej (art. 8 rozporządzenia).

Trudno nie zgodzić się, że ważnym prądem oddziaływania, a tym samym i kształtowania unijnego aquis communautaire są umowy międzynarodowe. Mają one na tyle dynamiczny charakter prawotwórczy, iż w obecnym czasie można już mówić o wyodrębnieniu samodzielnego działu prawa, jakim jest międzynarodowe prawo środowiska ${ }^{74}$. Doktryna mówiąc o źródłach tego prawa dzieli je na źródła prawa twardego hard law, do którego zaliczane są między innymi umowy międzynarodowe oraz soft law, czyli prawo miękkie w postaci wszelkich aktów niemających charakteru prawotwórczego jak deklaracje, zalecenia, zasady, standardy ${ }^{75}$. Umowa międzynarodowa, jako zasadnicze narzędzie tworzenia międzynarodowego prawa śro-

74 Por. L. Gardjan-Kawa, Zarys ewolucji prawa ochrony przyrody $i$ środowiska $w$ aspekcie międzynarodowym $i$ w Polsce, „Rzeszowskie Zeszyty Naukowe” 1999, nr 27, s. 122-133.

75 Por. szerzej M. Kenig-Witkowska, Międzynarodowe prawo środowiska, „Wolter Kluwer” 2011, s. 105 i nast. 
dowiska, ma w stosunku do prawa wewnętrznego szczególną pozycję ustrojową. Wdrażanie norm prawnomiędzynarodowych, jako instrument konstruujący zadania prawne dla organów krajowych, może mieć w umowach międzynarodowych różny kształt, co wynika z możliwości ich bezpośredniego lub pośredniego stosowania przez organy administracji. Dlatego też słusznie się zauważa, że w stosunku do podmiotów mieszczących się w strukturze administracji publicznej może to nastąpić zarówno przez włączenie odpowiedniego obowiązku do normatywnego katalogu zadań danej jednostki, jak i przez akt kierownictwa wewnętrznego ${ }^{76}$.

$\mathrm{Z}$ racji tematu przedmiotowego opracowania trzeba odnieść się do dwóch takich umów, to jest Konwencji o różnorodności biologicznej77, a zwłaszcza Konwencji o międzynarodowym handlu dzikimi zwierzętami i roślinami gatunków zagrożonych wyginięciem ${ }^{78}$ (dalej jako: Konwencja CITES lub Konwencja Waszyngtońska). Obie konwencje można sklasyfikować jako umowy międzynarodowe wielostronne (powszechne), które mają za zdanie ochronę różnorodności biologicznej jako dobra wspólnego całej ludzkości ${ }^{79}$.

76 M. Górski, Prawo międzynarodowe a ochrona warstwy ozonowej, „Studia Prawno-Ekonomiczne" 1997, t. 55, s. 80-81.

77 Konwencja o różnorodności biologicznej - załącznik A do decyzji Rady z dnia 25 października 1993 r. dotyczącej zawarcia Konwencji o różnorodności biologicznej (Dz.Urz. UE L 309, 13.12.1993, s. 1-20; tekst w języku polskim opublikowany w Dz.Urz. UE Polskie wydanie specjalne 2004, rozdz. 11, t. 19 , s. 126-145).

${ }^{78}$ Konwencja o międzynarodowym handlu dzikimi zwierzętami i roślinami gatunków zagrożonych wyginięciem - załącznik A do decyzji Rady z dnia 3 grudnia 1982 r. dotyczącej zawarcia Konwencji o międzynarodowym handlu dzikimi zwierzętami i roślinami gatunków zagrożonych wyginięciem (Dz.Urz. UE L 384, 31.12.1982, s. 7-54; tekst w języku polskim opublikowany w Dz.Urz. UE Polskie wydanie specjalne 2004, rozdz. 11, t. 15, s. 48-95).

${ }^{79}$ Klasyfikację umów międzynarodowych oraz problematykę ich stosowania podejmuje M. Woźnika: Aspekty stosowania umów międzynarodowych przez organy administracji na przykładzie prawa ochrony środowiska, w: B. Banaszak (red.), „Przegląd Prawa i Administracji”, t. 54, Wrocław 2003, s. 319-338, a także T. Wasilewski, Stosunek wzajemny: porządek międzynarodowy, prawo międzynarodowe, europejskie prawo wspólnotowe, prawo krajowe, Toruń 2004. 
Pokrótce omawiając konwencję o różnorodności biologicznej, trzeba zwrócić uwagę, że za kluczowy cel stawia ona sobie ochronę różnorodności biologicznej ${ }^{80}$, zrównoważone użytkowanie jej elementów oraz uczciwy i sprawiedliwy podział korzyści wynikających z wykorzystywania zasobów genetycznych, w tym przez odpowiedni dostęp do zasobów genetycznych i odpowiedni transfer właściwych technologii, z uwzględnieniem wszystkich praw do tych zasobów i technologii, a także odpowiednie finansowanie (art. 1 Konwencji). Drogą do osiągnięcia tego celu poza działaniami ogólnymi, identyfikacją elementów różnorodności biologicznej i ich monitoringiem jest ochrona in situ i ex situ. Słowniczek konwencji definiuje nam w art. 2, że „ochrona ex situ" to ochrona składników różnorodności biologicznej poza ich naturalnymi siedliskami i w zasadzie koresponduje to z zakresem definicji art. 5 pkt 6 polskiej ustawy o ochronie przyrody, który stwierdza, że ochrona ex situ, to ochrona gatunków roślin, zwierząt i grzybów poza miejscem ich naturalnego występowania oraz ochrona skał, skamieniałości i minerałów $\mathrm{w}$ miejscach ich przechowywania ${ }^{81}$. Nie bez przyczyny wybrałem właśnie ten termin prawny z szerokiej listy wymienionych w konwencji, gdyż jest on pośrednio powiązany ze sprawą, w której Sąd Rejonowy w Kościanie skierował do Trybunału Sprawiedliwości pytanie prejudycjalne. Prowadzone postępowanie karne przeciwko Tomaszowi R. dotyczyło hodowli w warunkach domowych zwierząt z gatunku pajęczaków, a więc hodowli poza ich naturalnym siedliskiem, co w świetle przepisów konwencji winno kreować w naszym systemie prawnym pewne konkretne obowiązki i ograniczenia w ramach wy-

80 Por. A. Przyborowska-Klimczak, Pojęcie różnorodności biologicznej $w$ świetle międzynarodowego prawa ochrony przyrody, „Prawo-Administracja-Kościół" 2000, nr 4 s. 105-117.

81 Funkcjonujący w Polsce system ochrony ex-situ był przedmiotem kontroli kompleksowej NIK - Najwyższa Izba Kontroli - Departament Środowiska, Rolnictwa i Zagospodarowania Przestrzennego, „Informacja o wynikach kontroli. Przygotowanie do wypełniania przez Polskę ratyfikowanej w 1996 r. międzynarodowej Konwencji o różnorodności biologicznej (podpisanej w Rio Janerio dnia 5 czerwca 1992)", NIK Warszawa luty 2004, Nr ewid. 11/2004/P/03/116/KSR, s. 71-73. 
pełniania postulatów ochrony ex situ. Mam tu na myśli art. 9 lit. d Konwencji, który mówi, iż strona konwencji reguluje i kieruje pozyskiwaniem zasobów biologicznych z naturalnych siedlisk dla ochrony ex-situ w taki sposób, aby nie zagrażało ono ekosystemom i populacjom gatunków in-situ z wyjątkiem sytuacji, w których specjalne tymczasowe działania ex-situ są niezbędne w celu restytucji i odtworzenia zagrożonych gatunków oraz ich ponownego wprowadzenia do ich naturalnych siedlisk przy zachowaniu odpowiednich warunków. Polska ustawa o ochronie przyrody przewiduje szereg działań ochronnych w ramach ochrony ex-situ, jednak jak dowiodę tego w dalszej części publikacji, nie zawsze przepisy konstruujące tę ochronę są na tyle kompleksowe, iż mogą być skutecznym instrumentem wypełniającym ogólne cele środowiskowe.

Najważniejszym aktem prawnomiędzynarodowym budującym zręby ochrony gatunkowej w procesie handlu okazami dzikich gatunków zwierząt i roślin jest Konwencja CITES ${ }^{82}$. Jej narzędzia prawne zostały $\mathrm{w}$ zasadzie wprost przeniesione do rozporządzenia w sprawie ochrony gatunków dzikiej fauny i flory w drodze regulacji handlu nimi ${ }^{83}$. Wskazuje na to chociażby art. 1 poprzez sformułowanie, że niniejsze rozporządzenie stosuje się zgodnie z celami, zasadami i postanowieniami Konwencji (Konwencji CITES - mój przypis). Unia Europejska nie jest stroną CITES. Przysługuje jej jedynie status obserwatora przy Konferencji Stron Konwencji CITES, co przekłada się na prawo uczestniczenia w jej sesjach bez prawa głosu (art. XI ust. 6 Konwencji Waszyngtońskiej) z możliwością jednak przedstawienia stanowiska w kwestiach będących przedmiotem obrad. Wspólne stanowisko przyjmowane jest przez Radę Unii Eu-

82 Kierunki rozwoju Konwencji CITES bada W. Wijnstekers, The Evolution on of CITES, International Council for Game and Wildlife Conservation, $9^{\text {th }}$ edition on 2011, s. 941 oraz G. Di Plinio, La CITES al vaglio della Corte: la disciplina degli esemplari in cattività di specie minacciate di estinzione tra protezionismo francese, diritto comunitario ambientale e principio di libertà di circolazione delle merci, Diritto Pubblico Comparato ed Europeo 2002, s. 419-425.

83 Por. M. Stępień, Rejestrowanie zwierząt $i$ roślin podlegających ograniczeniom na podstawie konwencji waszyngtońskiej, „Prawo i Środowisko” 2004, nr 1, s. 133-138. 
ropejskiej w drodze decyzji ${ }^{84}$, która wywołuje wiążące skutki prawne nie tylko wobec Unii i jej organów, ale także wobec jej państw członkowskich w zakresie, w jakim nakłada na nie obowiązek obrony i popierania tego stanowiska ${ }^{85}$.

Sygnatariusze konwencji nade wszystko uznali, że dzikie zwierzęta i rośliny w ich wielorakich, pięknych i różnorodnych formach stanowią niezastąpioną część naturalnych systemów przyrody ziemskiej, która musi być zachowana dla obecnych i przyszłych pokoleń. Do ich ochrony powołane są zarówno państwa, jak i społeczeństwa, a współpraca międzynarodowa jest podstawowym czynnikiem ochrony niektórych z gatunków dzikich zwierząt i roślin przed nadmierną niezrównoważoną eksploatacją powodowaną handlem międzynarodowym. Podobnie jak w rozporządzeniu w sprawie ochrony gatunków dzikiej fauny i flory w drodze regulacji handlu nim, tak i w Konwencji CITES za podstawową zasadę przyjmuje się reglamentacje handlu niektórymi gatunkami chronionymi poprzez zdefiniowanie wymogów prawnych co do ich obrotu. Postulat ten znajduje swoje odbicie w trzech załącznikach do konwencji.

Pierwszy załącznik obejmuje gatunki, co do których stwierdzono, że są one zagrożone wyginięciem. Natomiast drugi to spis gatunków, które nie są zagrożone, ale mogą być, jeśli han-

84 Zgodnie z orzecznictwem ważną przesłanką ważności takiej decyzji jest jej podjęcie przez Radę w oparciu właściwą podstawę prawną - por. Wyrok Trybunału z dnia 1 października 2009 r. Komisja Europejska przeciwko Radzie Unii Europejskiej - sprawa C-370/07 (Dz. UE C 282, 21.11.2009, s. 4).

85 Obecnie Polska w celu poparcia stanowiska Komisji Europejskiej oraz innych państw członkowskich Unii, a wbrew wnioskom Republiki Indii, dotyczącym objęcia ochroną niektórych z podgatunków lisa oraz łasicowatych, podjęła inicjatywę legislacyjną w zakresie zgłoszenia zastrzeżeń do załącznika III do Konwencji CITES - Por. projekt ustawy z dnia 8 lutego 2013 r. o zmianie zakresu obowiązywania Konwencji o międzynarodowym handlu dzikimi zwierzętami i roślinami gatunków zagrożonych wyginięciem sporządzonej w Waszyngtonie dnia 3 marca 1973 r. oraz Sejm RP - Komisja Ochrony Środowiska, Zasobów Naturalnych i Leśnictwa, uzasadnienie do „Rządowy projekt ustawy o zmianie zakresu obowiązywania Konwencji o międzynarodowym handlu dzikimi zwierzętami i roślinami gatunków zagrożonych wyginięciem, sporządzonej w Waszyngtonie dnia 3 marca 1973 r., przez zgłoszenie zastrzeżeń do jej Załącznika III", w: Druk Sejmowy Nr 1011, Warszawa 17 grudnia 2012 r., http://www.sejm.gov.pl/Sejm7.nsf/PrzebiegProc.xsp?nr=1011. 
del nimi nie zostanie ograniczony. Trzeci załącznik obejmuje gatunki, w stosunku do których handel został poddany kontroli na wniosek chociaż jednej ze stron Konwencji CITES. Warunkiem legalnego handlu wszystkimi okazami gatunków są wydane w odpowiednim trybie przez krajowe organy administracyjne świadectwa lub zezwolenia ${ }^{86}$. Konwencja ustala jedynie ogólne wymogi formalne takich dokumentów, pozostawiając ich doprecyzowanie poszczególnym sygnatariuszom ${ }^{87}$. W samej Polsce z danych statystycznych wynika, że w 2000 roku służby celne zatrzymały nielegalny przemyt 1706 okazów gatunków w związku z naruszeniem przepisów Konwencji CITES, a w roku 2011 liczba ta wzrosła już do 8495 sztuk $^{88}$. W 2010 r. wydano zezwolenia na import do Polski 100 okazów żywych gatunków pajęczaków sklasyfikowanych w załączniku II do Konwencji.

Mówiliśmy o tym przy okazji rozporządzenia w sprawie ochrony gatunków dzikiej fauny i flory w drodze regulacji handlu nimi, ale także Konwencja Waszyngtońska zawiera specjalne postanowienia dotyczące handlu okazami gatunków urodzonymi w niewoli. Chodzi tutaj o treść art. VII ust. 4 i 5, który stwierdza, że okazy gatunków zwierząt objętych załącznikiem I, rozmnażane w niewoli dla celów handlowych, lub gatunków roślin objętych załącznikiem I, sztucznie rozmnażanych dla celów handlowych, będą uważane za okazy gatunków objętych załącznikiem II. Natomiast, jeżeli organ zarządzający państwa

${ }^{86}$ Por. Ch. Fuchs, Convention on International Trade in Endangered Species of Wild Fauna and Flora (CITES) Conservation Efforts Undermine the Legality Principle, w: Armin von Bogdandy, Rüdiger Wolfrum, Jochen von Bernstorff, Philipp Dann, Matthias Goldmann (red.), The Exercise of Public Authority by International Institutions - Advancing International Institutional Law, Springer 2010, s. 475-508.

87 Funkcjonowanie systemu świadectw i zezwoleń na przykładzie Holandii ocenia I. M. Koopmans, Strafrechtelijke handhaving van CITES en aanverwante regelgeving in Nederland, w: Ingeborg Marjolein Koopmans, Jonathan Verschuuren (red.), Handhaving van Europees milieurecht in Nederland, Boom Juridische Uitgevers 2000, s. 59-74, a w odniesieniu do Austrii K.H. Fischer, Naturschutz, Österreich und das Umweltrecht der Europäischen Union, Wien Ueberreiter 1996, s. 379-396.

88 Główny Urząd Statystyczny „Ochrona Środowiska 2011. Informacje i opracowania statystyczne", Warszawa 2011, s. 316. 
wywozu ustali, że okaz określonego gatunku zwierząt został wyhodowany w niewoli lub okaz gatunku roślin został sztucznie wyhodowany albo że chodzi o część takiego zwierzęcia lub rośliny lub też o otrzymany z nich produkt, wydane przez organ zarządzający świadectwo stwierdzające ten fakt będzie akceptowane zamiast zezwoleń lub świadectw wymaganych zgodnie z postanowieniami artykułów III, IV lub V.

Na przestrzeni ostatnich lat instytucje unijne coraz częściej zauważają konieczność wzmożenia wspólnych wysiłków i koordynacji w celu lepszego egzekwowania postanowień Konwencji CITES $^{89}$. Aktualnie rynek Unii Europejskiej to największy obszar nielegalnego handlu dzikimi gatunkami, a przestrzeganie prawa na tyle różni się w poszczególnych państwach członkowskich, że jego jednolite wdrożenie staje się praktycznie niemożliwe do wykonania.

\section{PREJUDYCJALNOŚĆ W OCHRONIE PRZYRODY - POSTULATY DE LEGE FERENDA}

Ochrona elementów przyrody, jako jeden z komponentów ochrony środowiska, jest sferą na tyle wrażliwą na degradację, że pożądane jest, aby wszelkie procedury prawne $\mathrm{z}$ nią zespolone uwzględniały tę specyfikę i gwarantowały możliwe szybkie rozstrzygnięcia w odniesieniu do pojawiających się zdarzeń czy zagrożeń. Aksjomat ten trudno jednak osiągnąć, zważywszy na dość rozbudowaną konstrukcję instrumentów prawnych, z których zbudowany jest cały system. W obrębie styku prawa unijnego z prawami państw członkowskich, pojawia się instytucja pytań prejudycjalnych, które ujednolicają istniejący $\mathrm{w}$ tym obszarze porządek prawny.

89 Por. Rezolucja Parlamentu Europejskiego z dnia 10 lutego 2010 r. w sprawie strategicznych celów UE na 15. sesję Konferencji Stron Konwencji o Międzynarodowym Handlu Dzikimi Zwierzętami i Roślinami Gatunków Zagrożonych Wyginięciem (CITES), która odbędzie się w Ad-Dausze (Katar) w dniach 13-25 marca 2010 r. (Dz.Urz. UE C 341 E, 16.12.2010, s. 43-48). 
Statystyki Trybunału Sprawiedliwości Unii Europejskiej akcentują trend $\mathrm{w}$ postaci zwiększania $\mathrm{z}$ roku na rok liczby postępowań mających za przedmiot odesłanie prejudycjalne. W 2007 r. takich postępowań było 265, a w 2011 r. jest już ich aż 423, z czego zdecydowanie dominującą pozycję stanowią sprawy podatkowe, natomiast kwestię środowiskowe plasują się dopiero na szóstym miejscu ex aequo z zagadnieniami dotyczącymi swobodnego przepływu kapitału, transportu oraz unii celnej i wspólnej taryfy celnej ${ }^{90}$. Dalsza analiza uwidacznia nam, że czas trwania postępowania zainicjowanego pytaniem prejudycjalnym waha się średnio od około 19 miesięcy w roku 2007 do około 16 miesięcy w roku 2011. W mojej ocenie okres potrzebny do wydania orzeczenia $\mathrm{w}$ tym przedmiocie jest mimo to nadal zbyt długi, co może wpływać szczególnie negatywnie na pogorszenie stanu ochrony w sprawach środowiskowych. Temat publikacji, a także ustanowienie nowego regulaminu postępowania przed Trybunałem Sprawiedliwości ${ }^{91}$ (dalej jako: regulamin postępowania przed Trybunałem), który wszedł w życie z dniem 1 listopada 2012 r., skłoniły mnie jednak do zaproponowania pewnych rozwiązań w tym przedmiocie. Na początku poczyńmy jednak pewne krótkie dygresje o istocie pytań prejudycjalnych kierowanych do Trybunału Luksemburskiego, a ułatwi nam to późniejsze uchwycenie kontekstu nakreślonych przeze mnie zmian, które mogą znacząco poprawić funkcjonowanie tej instytucji $\mathrm{w}$ odniesieniu do systemu prawa ochrony środowiska.

Instytucja odesłania wstępnego lub prejudycjalnego (ang. preliminary reference, fr. renvoi prẻjudiciel) sprowadza się, ogólnie rzecz mówiąc, do interpretacji przez Trybunał prawa unijnego w sprawie zawisłej przed sądem krajowym, gdy sąd ten napotka trudności w procesie wykładni tego prawa. Wątpliwości interpretacyjne muszą być racjonalne i uzasadnione, w prze-

90 Trybunał Sprawiedliwości Unii Europejskiej, „Sprawozdanie roczne 2011 r.", s. 112, http://curia.europa.eu/jcms/upload/docs/application/ pdf/2012-06/ra2011_statistiques_cour_pl.pdf.

91 Regulaminy wewnętrzne - Regulamin postępowania przed Trybunałem Sprawiedliwości, (Dz.Urz. UE L, 29.09.2012, s. 1-42). 
ciwnym razie Trybunał winien odmówić wydania orzeczenia prejudycjalnego zgodnie z doktryną aktu jasnego acte clair, to jest wtedy, gdy stosowana norma jest w pełni jasna i precyzyjna. Koncepcja ta musi znaleźć odzwierciedlenie przy porównaniu różnych wersji językowych aktu prawa unijnego z zastosowaniem właściwej dla tego aktu terminologii oraz linii orzeczniczej wszystkich państw członkowskich ${ }^{92}$. Dyrektywy wykładni przepisu unijnego powinny uwzględniać w takim przypadku jego miejsce zarówno w samym akcie prawnym, jak i całym systemie prawa. Przesłanką mogącą zwolnić sąd krajowy z zobowiązania zwrócenia się do Trybunału z pytaniem prejudycjalnym związana jest doktryną aktu wyjaśnionego acte éclairẻ, to jest, gdy dane zagadnienie prawa unijnego zostało już wyjaśnione przez Trybunał we wcześniejszym orzecznictwie, bez względu na rodzaj postępowania, w którym to nastąpiło, jednak w sprawach o identycznym lub podobnym stanie faktycznym ${ }^{93}$. Nowatorskim podejściem w obecnym regulaminie postępowania Trybunału do doktryny aktu wyjaśnionego jest możliwość udzielenia odpowiedzi w formie postanowienia z uzasadnieniem (art. 99), jeżeli pytanie skierowane $\mathrm{w}$ trybie prejudycjalnym jest identyczne z pytaniem, w którego przedmiocie Trybunał już orzekał, jeżeli odpowiedź na pytanie prejudycjalne można wywieść w sposób jednoznaczny z orzecznictwa lub jeżeli odpowiedź na pytanie prejudycjalne nie pozostawia żadnych uzasadnionych wątpliwości. Orzeczenie takie zapaść może w każdym stadium postępowania, na wniosek sędziego sprawozdawcy i po zapoznaniu się ze stanowiskiem rzecznika generalnego.

Materialnoprawnym fundamentem do wystąpienia przez sąd krajowym z pytaniem prejudycjalnym do Trybunału Luksemburskiego jest art. 267 Traktatu o funkcjonowaniu Unii Europejskiej94 (dawny art. 234 Traktatu ustanawiającego Wspólno-

92 Szerzej E. Piontek, Doktryna i praktyka „acte clair”, a wspólnotowy porządek prawny $w$ kontekście funkcji art. 234 TWE", E. Piontek, A. Zawadzka (red.), Prawo polskie a prawo Unii Europejskiej”, Warszawa 2003.

93 Szerzej C.I. Kamiński, Wymiar Sprawiedliwości we Wspólnocie Europejskiej. Praktyczny komentarz i przepisy, LexisNexis, Warszawa 2004.

94 Traktat o funkcjonowaniu Unii Europejskiej, op.cit., s. 164. 
tę Europejską). Trybunał na jego podstawie orzeka o ważności traktatów lub o ważności i wykładni aktów przyjętych przez instytucje, organy lub jednostki organizacyjne Unii. W żadnym wypadku jednak Trybunał nie jest wyposażony w kompetencję do interpretowania prawa krajowego, czy też wypowiadania się, co do jego ewentualnej zgodności z prawem unijnym. Pomimo tego zastrzeżenia może on sądowi krajowemu określić kryteria umożliwiające rozstrzygnięcie zawisłego przed nim sporu z punktu widzenia potencjalnej sprzeczności czy też niezgodności stosowanych norm prawa. Sąd państwa członkowskiego każdorazowo swobodnie decyduje o tym, czy ma się zwrócić do Trybunału Sprawiedliwości o wydanie orzeczenia wstępnego, jeżeli orzeczenie takie jest niezbędne do wydania wyroku, a postanowienie $\mathrm{w}$ tym przedmiocie jest niezależne od żądań stron $\mathrm{w}$ postępowaniu głównym ${ }^{95}$. Uznaniowość $\mathrm{w}$ tym przedmiocie jest jednak wyłączona, gdy orzeczenie sądu państwa członkowskiego nie podlega zaskarżeniu według prawa wewnętrznego i chodzi tutaj przede wszystkim o stan prawny, w którym stronie w ściśle określonym przypadku nie przysługuje już żaden środek odwoławczy, a nie o wykluczenie dalszego trybu odwoławczego $\mathrm{z}$ racji usytuowania danego sądu w hierarchii organów orzekających $^{96}$. Zaniechanie obowiązku wystąpienia do Trybunału o rozstrzygnięcie zagadnienia prawnego może być uznane za poważne naruszenie prawa traktatowego, co implikuje odpowiedzialność odszkodowawczą danego państwa członkowskiego. Orzecznictwo Sądu Luksemburskiego wypracowało ważną zasadę, zgodnie z którą sąd krajowy niższego rzędu, pomimo związania w kwestiach prawnych wyrokiem sądu wyższego, nie traci na tej podstawie uprawnień do wystąpienia $\mathrm{z}$ pytaniem prejudycjalnym. Idąc dalej, Trybunał stoi na stanowisku, że samodzielność kompetencyjna do wystąpienia z pytaniem prejudycjalnym oznacza również możliwość pominięcia wiążących

95 Por. R. Talaga, Pytania prejudycjalne do Trybunału Sprawiedliwości UE w praktyce polskich sq̨dów administracyjnych, „Studia Europejskie”, Warszawa 2010, s. 91-115.

96 Szerzej M. Taborowski, Konsekwencje naruszenia prawa Unii Europejskiej przez sądy krajowe, Warszawa 2012, s. 35-42. 
wskazań sądu wyższej instancji, wydanych w postępowaniu odwoławczym, jeżeli te uniemożliwiałyby wystąpienie prejudycjalne ${ }^{97}$. Z przywileju tego skorzystał Sąd Rejonowy w Kościanie, ponieważ po wydaniu orzeczenia prejudycjalnego stwierdził, że w jego ocenie wskazania dowodowe nim podyktowane są nie do pogodzenia z wytycznymi Sądu Okręgowego ${ }^{98}$, który przekazała mu sprawę do ponownego rozpoznania na skutek apelacji prokuratury. Zważywszy na to, uchylił się od ich zastosowania.

Nauka prawa, badając sposób formułowania pytań prawnych, stawia tezę, że Trybunał akceptuje tylko tzw. pytania zamknięte, czyli takie, na które odpowiedź może być albo pozytywna, albo negatywna, natomiast nie akceptuje pytań otwartych, które uznaje za zbyt abstrakcyjne i hipotetyczne, niepowiązane wystarczająco z postępowaniem głównym, a w następstwie tego niemieszczące się w dyspozycji art. 267 TFUE $^{99}$. Nowością w procedurze prejudycjalnej jest to, iż regulamin postępowania przed Trybunałem w art. 94 określił formalne elementy wniosku o wydanie orzeczenia w trybie prejudycjalnym kierowanego do Trybunału Luksemburskiego, uprzednio de facto wynikały one raczej z praktyki orzeczniczej. Poza sformułowaniem pytań skierowanych do Trybunału wniosek o wydanie orzeczenia w trybie prejudycjalnym zawiera zwięzłe omówienie przedmiotu sporu oraz istotnych okoliczności faktycznych sprawy, jakie ustalił sąd odsyłający lub co najmniej wskazanie okoliczności faktycznych, na jakich oparte są pytania. Ponadto we wniosku musi być podana treść przepisów krajowych mogących mieć zastosowanie w sprawie oraz, w stosownym przypadku, wskazanie istotnego dla sprawy orzecznictwa sądów krajowych, a tak-

97 Problematykę tę omawia N. Półtorak, Procedura prejudycjalna - wprowadzenie $i$ wyrok Trybunału z 14.01.1974 r. w sprawie 166/73 RheinmühlenDüsseldorf v. Einfuhr- und Vorratsstelle für Getreide und Futtermittel, " Europejski Przegląd Sądowy" 2010, nr 8, s. 58 i nast.

98 Wyrok Sądu Okręgowego w Poznaniu IV Wydział Karno - Odwoławczy z dnia 2 kwietnia 2008 r., sygn. akt IV Ka 4/08, nie publik.

99 Szerzej (red.) J. Barcz, Prawo Unii Europejskiej. Zagadnienia systemowe, „Prawo i Praktyka Gospodarcza”, Warszawa 2006, s. 364 oraz A. Rigaux, Compétence de la Cour et recevabilité des questions préjudicielles, Europe 2012, Août Septembre Comm, nr 8-9, s. 20-21. 
że omówienie powodów, dla których sąd odsyłający rozpatruje kwestię wykładni lub ważności określonych przepisów prawa Unii Europejskiej, jak również związku, jaki dostrzega on między tymi przepisami, a uregulowaniami krajowymi, które znajdują zastosowanie w postępowaniu głównym. Nowy regulamin postępowania zobowiązuje Trybunał do utajnienia tożsamości stron przy rozstrzyganiu pytania prejudycjalnego, jeżeli o takim utajnieniu zdecydował wcześniej sąd odsyłający (art. 95 ust. 1 regulaminu postępowania przed Trybunałem). Trybunał o utajnieniu tożsamości może zdecydować także na wniosek sądu odsyłającego na należycie uzasadniony wniosek strony w postępowaniu głównym lub z urzędu, jeśli uzna to za właściwe. Przepisy te nabierają szczególnego znaczenia przede wszystkim w sprawach karnych, gdzie informacje o danych osobowych oskarżonego były, na skutek obowiązku publikacji w dzienniku urzędowym UE, dostępne dla podmiotów trzecich nawet po zakończeniu postępowania i zatarciu skazania. Na niedopuszczalność istnienia takiego stanu prawnego zwracali uwagę od pewnego czasu pełnomocnicy procesowi potencjalnych strony takich postępowań ${ }^{100}$. Wskazane okoliczności odnoszą się także do postępowania karnego prowadzonego przez Sąd Rejonowy w Kościanie, w którym skierowano do Trybunału pytanie prejudycjalne analizowane w niniejszej publikacji.

Orzeczenie Trybunału Sprawiedliwości wydane w postępowaniu prejudycjalnym wiążą wszystkie sądy, które w toku instancyjnym rozpoznają daną sprawę, w której powstało zagadnienie wstępne. Praktyka sądowa przyjmuje również, że przedmiotowe orzeczenie winno być stosowane także do innych podobnych spraw, wyłaniających się w judykaturze danego państw członkowskiego, a więc ma ono skutek erga omnes. Skutek ten występuje także w momencie, gdy Trybunał ustalił nieważność przepisu lub aktu wchodzącego w skład prawa unijnego ${ }^{101}$. Co warto podkreślić, Trybunał nie orzeka ani w przed-

100 Szerzej T. Trych, Tożsamość oskarżonego bez ochrony, „Dziennik Gazeta Prawna B", 16.07.2012, nr 136, s. 9

101 Por. P. Dąbrowska-Kłosińska, Skutki wyroków prejudycjalnych TS w postępowaniu przed sądami krajowymi w świetle orzecznictwa i Traktatu z Lizbo- 
miocie kwestii faktycznych podniesionych $\mathrm{w}$ ramach sporu przed sądem krajowym, ani w przedmiocie różnic $\mathrm{w}$ opiniach na temat wykładni lub stosowania przepisów prawa krajowego. Orzeczenie prejudycjalne Trybunału odtwarza sens przepisu $\mathrm{w}$ momencie jego ustanowienia przez ustawodawcę, a więc wywołuje skutek ex tunc, co oznacza, że wykładnia reguluje stosunki prawne przed wydaniem danego orzeczenia. W niektórych przypadkach Trybunał może jednak ograniczyć skutek wsteczny do momentu wydania orzeczenia albo też wyznaczyć go od daty wniesienia sprawy ${ }^{102}$.

Nowy regulamin postępowania Sądu Luksemburskiego przewiduje dla pewnej kategorii spraw dwa znowelizowane szczególne tryby prejudycjalne, tj. przyśpieszony tryb prejudycjalny oraz pilny tryb prejudycjalny. Mogą one stanowić w mojej opinii właściwe narzędzie do rozstrzygania pytań prejudycjalnych sądów krajowych w sprawach środowiskowych, aczkolwiek nasuwa to potrzebę zmiany zarówno przepisów prawa unijnego, jak i praktyki judykacyjnej panującej wśród sądów państw członkowskich.

Tryb przyśpieszony przy rozpoznaniu przez Trybunał pytania prejudycjalnego może być użyty w każdym rodzaju sprawy, a więc także w sprawie środowiskowej, jeżeli jej charakter wymaga niezwłocznego rozstrzygnięcia (por. art. 105 regulaminu postępowania przed Trybunałem). Zastosowanie tego trybu następuje na wniosek sądu krajowego występującego z pytaniem prejudycjalnym, a tylko w drodze wyjątku z urzędu może zadecydować o tym sam Trybunał. Decyzję o rozstrzygnięciu $\mathrm{w}$ trybie przyśpieszonym podejmuje prezes Trybunału po zapoznaniu się ze stanowiskiem sędziego sprawozdawcy i rzecznika generalnego. W wyniku skorzystania $\mathrm{z}$ tego trybu postępowania zostaje natychmiast wyznaczony termin rozprawy, a terminy składania pism procesowych przez strony postępowania nie mogą być krótsze niż 15 dni od daty wyznaczenia przez prezesa Trybunału. W celu zachowania zasady szybkości postępowania

ny", " Europejski Przegląd Sądowy" 2010, nr 12, s. 4-15.

102 Tak J. Zięba, Instytucja orzeczeń wstępnych Trybunału Wspólnot Europejskich, „Studia Prawnicze” 2004, nr 4, s. 83. 
prezes może wzywać podmioty do ograniczenia dokumentów procesowych do zasadniczych kwestii prawnych podniesionych we wniosku o wydanie orzeczenia $\mathrm{w}$ trybie prejudycjalnym. Ewentualne dokumenty procesowe przekazuje się wszystkim podmiotom przed rozprawą. Trybunał orzeka po zapoznaniu się ze stanowiskiem rzecznika generalnego. Sprawozdania roczne Trybunału Sprawiedliwości podają nam, że w 2007 r. $\mathrm{w}$ trybie przyśpieszonym $\mathrm{w}$ ramach odesłania prejudycjalnego było rozpoznawanych 7 spraw, a w roku 2011 było ich już $13^{103}$. Niestety żadna z nich nie dotyczyła ochrony przyrody, czy ogólnie rzecz mówiąc, spraw środowiskowych. Jest to stan rzeczy szczególnie zastanawiający, tym bardziej, że zastosowanie tego trybu następuje w zasadzie na wniosek sądu odsyłającego, a więc do jego kompetencji należy ocena, czy stan faktyczny spraw, rodzaj dokonanych naruszeń oraz długość postępowania prejudycjalnego może spowodować pogorszenie stanu ochrony środowiska. Uważam, że w obecnym dynamicznym etapie ewaluacji postępowania przed Sądem Luksemburskim sądy krajowe powinny skłonić się ku korzystaniu z przyśpieszonego trybu prejudycjalnego, gdyż może on zagwarantować w koniecznym zakresie zabezpieczenie celów prawnośrodowiskowych. Walory te są nie do przecenienia, lecz twierdzę, że mogą być one brane pod uwagę $\mathrm{w}$ postępowaniach przed sądem państwa członkowskiego i pytaniach prejudycjalnych szczególnie ważnych z ekologicznego punktu widzenia.

Drugim dość ważnym trybem postępowania przy pytaniach prejudycjalnych obowiązującym od dnia 1 marca 2008 r. $^{104}$ jest pilny tryb prejudycjalny uregulowany w art. 107 do 114 regulaminu postępowania przed Trybunałem Sprawiedliwości, który odnosi się do przestrzeni wolności, bezpieczeństwa i sprawiedliwości, a umiejscowiony jest w Tytule V części trzeciej Traktatu o funkcjonowaniu Unii Europejskiej ${ }^{105}$.

103 Trybunał Sprawiedliwości Unii Europejskiej, „Sprawozdanie roczne 2011 r.", op. cit., s. 115.

104 Art. 2 Regulaminu zmieniającego Regulamin Trybunału Sprawiedliwości (Dz.Urz. UE L 24, 29.01.2008, s. 41).

105 Traktat o funkcjonowaniu Unii Europejskiej, op.cit., s. 73-84. 
Przesłanką do posługiwania się nim był art. 35 TUE (Traktatu o Unii Europejskiej) oraz art. 68 TWE (Traktatu ustanawiającego Wspólnotę Europejską) ${ }^{106}$, które zostały następnie uchylone przez Traktat z Lizbony ${ }^{107}$, reformujący ustrój Wspólnoty Europejskiej między innymi poprzez zniesienie trzech filarów, co spowodowało, że Trybunał Sprawiedliwości uzyskał w tym obszarze ogólne właściwości prejudycjalne. Wskazane jest zauważyć, że po wprowadzeniu pilnego trybu prejudycjalnego, lecz przed wejściem w życie Traktatu z Lizbony jedynie 4,85\% odesłań prejudycjalnych dotyczyło przestrzeni wolności, bezpieczeństwa i sprawiedliwości. W rozpoznawanych sprawach w pilnym trybie prejudycjalnym do października 2011 r. połowa dotyczyła jurysdykcji oraz uznawania i wykonywania orzeczeń w sprawach małżeńskich i w sprawach dotyczących odpowiedzialności rodzicielskiej. Jedna czwarta z nich dotyczyła europejskiego nakazu aresztowania. Wreszcie kolejną czwartą część z nich stanowiły sprawy z dziedziny „wiz, azylu i imigracji" ${ }^{\prime 108}$. Należy wspomnieć, że przepis art. 267 TFUE (Traktatu o funkcjonowaniu Unii Europejskiej) stanowi, że jeżeli pytanie prejudycjalne jest podniesione w sprawie zawisłej przed sądem krajowym dotyczącej osoby pozbawionej wolności, Trybunał ma stanowić w jak najkrótszym terminie. Piśmiennictwo dostrzega, że „możliwość zadawania przez sądy pytań prejudycjalnych $\mathrm{w}$ pilnym trybie współpracy policyjnej i sądowej w sprawach karnych przestała być uzależniona od złożenia przez państwo członkowskie oświadczenia uznającego właściwość TS oraz wskazującego sądy upoważnione do występowania z pytaniami. Należy jednak pamiętać, że zgodnie z przepisami przejściowymi, które mają obowiązywać maksymalnie przez okres pięciu lat, powszechna właściwość TS w tym zakresie ma zastosowa-

106 Specyfikę właściwości tej procedury omawiał (red.) J. Barcz, Postępowanie prejudycjalne..., s. 28 i nast.

107 Uchylenie nastąpiło na mocy art. 5 Traktatu z Lizbony zmieniającego Traktat o Unii Europejskiej i Traktat ustanawiający Wspólnotę Europejską (Dz. Urz. UE C 306, 17.12.2007, s. 134).

108 Trybunał Sprawiedliwości, „Sprawozdanie z wdrożenia przez Trybunał Sprawiedliwości pilnego trybu prejudycjalnego”, s. 4, http://curia.europa.eu/ jcms/upload/docs/application/pdf/2012-07/pl_rapport.pdf. 
nie tylko wobec nowych aktów prawnych. Natomiast w przypadku aktów prawnych z dziedziny współpracy policyjnej i sądowej w sprawach karnych, przyjętych przed wejściem w życie Traktatu z Lizbony, pytania prejudycjalne mogą być zadawane jedynie przez sądy, które zostały do tego upoważnione na mocy wspomnianego oświadczenia państwa członkowskiego ${ }^{109 "}$ ".

Intencją moją nie jest rozważanie wszystkich konstytutywnych cech pilnego trybu prejudycjalnego, lecz ukazanie niektórych z jej pozytywnych atrybutów, które stanowiłyby ratio legis do posługiwania się nim także w sprawach środowiskowych. Fundamentalną doniosłość ma, po pierwsze, badana przeze mnie na wstępie niniejszego rozdziału szybkość postępowania. Otóż w pilnym trybie prejudycjalnym udzielenie odpowiedzi przez Trybunał na zadane pytanie oscyluje w horyzoncie czasowym od 2,1 miesiąca w roku 2008 do 2,5 miesiąca w roku $2011^{110}$. Zastosowanie tego trybu, zgodnie z wytycznymi Trybunału, należy stosować tylko w sytuacjach wyjątkowych, gdy nieodzowne jest uzyskanie odpowiedzi w bardzo krótkim terminie $^{111}$. W praktyce nie jest jednak możliwe wyczerpujące wyliczenie wszystkich potencjalnych sytuacji, przede wszystkim ze względu na zróżnicowany i rozwojowy charakter przepisów Unii Europejskiej regulujących zagadnienia przestrzeni wolności, bezpieczeństwa i sprawiedliwości. Dlatego też pilny tryb prejudycjalny uwzględnia się na wniosek sądu pytającego lub w nadzwyczajnych przypadkach z urzędu (art. 107 § 1 regulaminu postępowania przed Trybunałem). Na sądzie odsyłającym leży formalny obowiązek przedstawia okoliczności prawnych i faktycznych wskazujących na pilny charakter sprawy, a także, w miarę możliwości, może on zaproponować Trybunałowi odpowiedź na postawione przez siebie pytania prejudycjalne.

109 A. Kastelik-Smaza, Pytanie prejudycjalne do Trybunału Sprawiedliwości Unii Europejskiej a ochrona praw jednostki, Wolters Kluwer Polska 2010, s. 23 i nast.

110 Trybunał Sprawiedliwości Unii Europejskiej, „Sprawozdanie roczne 2011 r.", op. cit., s. 112.

111 Trybunał Sprawiedliwości, „Zalecenia dla sądów krajowych, dotyczące składania wniosków o wydanie orzeczenia w trybie prejudycjalnym” (Dz.Urz. UE C 338, 06.11.2012, s. 5). 
Konstrukcja taka przyczynia się do zapewnienia szybkiego przebiegu postępowania poprzez uproszczenie zajęcia stanowiska przez strony w postępowaniu głównym i innych uczestników postępowania, a także przyśpiesza ona samą decyzję Trybunału. Połączenie w pilnym trybie prejudycjalnym przed Sądem Luksemburskim specjalnych uregulowań tyczących się pisemnego etapu postępowania oraz możliwości jego pominięcia ze specyficznymi zasadami doręczeń dokumentów procesowych (art. 109-111 regulaminu postępowania przed Trybunałem), są w mojej opinii trafnymi instrumentami prawnym przyczyniającym się do likwidacji przewlekłości postępowania.

Podsumowując rozważanie na temat prejudycjalności, jako narzędzia prawnego coraz częściej pojawiającego się w sprawach środowiskowych, uważam, że pożądane byłoby, aby sądy państw członkowskich w obecnym stanie prawa unijnego, zaczęły wykorzystywać atuty płynące z przyśpieszonego trybu prejudycjalnego, szczególnie tam, gdzie zachodzi niebezpieczeństwo szybkich i nieodwracalnych szkód. Pilny tryb prejudycjalny mógłby być stosowany również $\mathrm{w}$ takiej kategorii spraw, lecz dopiero $\mathrm{w}$ niedalekiej przyszłości, ponieważ wymaga to wprowadzenia dość istotnych zmian traktatowych, proceduralnych, jak i rozszerzenia samej struktury Trybunału Sprawiedliwości, ze względu na dość duże obciążenie liczbą corocznie rozpoznawanych przez niego spraw.

\section{BIBLIOGRAFIA}

Arnull A., Having your Cake and Eating it Ruled Out, "European Law Review/; 1988.

Bałaban A., Pawelec R., Dąbek D., Malinowski A. (red.), Kędziora P., Piotrowski R., Zarys metodyki pracy legislatora. Ustawy - akty wykonawcze - prawo miejscowe, Warszawa 2009.

Banaszak B., Konstytucja Rzeczpospolitej Polskiej. Komentarz, Warszawa 2012, Wydanie II.

Bar M., Jendrośka J., Umowy międzynarodowe EKG ONZ z dziedziny ochrony środowiska oraz zasady ich przestrzegania", Centrum Prawa Ekologicznego, Wrocław 2004. 
Barcz J. (red.), Prawo Unii Europejskiej. Zagadnienia systemowe, „Prawo i Praktyka Gospodarcza", Warszawa 2006.

Barcz J. (red.), Postepowanie prejudycjalne w przestrzeni wolności, bezpieczeństwa i sprawiedliwości Unii Europejskiej, Warszawa 2007.

Bielska-Brodziak A., Tkacz S., Tobor Z., Kilka uwag o wykładni prawa karnego, „Studia Prawnicze”, Warszawa 2009, nr 3.

Biernat S., Wykładnia prawa krajowego zgodnie z prawem wspólnotowym", w: C. Mik (red.), Implementacja prawa integracji europejskiej $w$ krajowych porządkach prawnych, Torun 1998.

Boiret K., Boiret A., Odpowiedzialność państw członkowskich UE w dziedzinie ochrony środowiska naturalnego, w: Kozłowski A., Mielnik B. (red.), Odpowiedzialność międzynarodowa, jako element międzynarodowego porzadku prawnego, „Acta Uniwersitatis Wratislaviensis", nr 3140, Wydawnictwo Uniwersytetu Wrocławskiego 2009.

Brodecki Z., Koncewicz T., Kupczyk P., Pchałek M., Ochrona przyrody przed Europejskim Trybunałem Sprawiedliwości. Komentarz, Ogólnopolskie Towarzystwo Ochrony Ptaków, Marki 2010.

Brzeziński P., Unijny obowiązek odmowy zastosowania przez sąd krajowy ustawy niezgodnej z dyrektywa Unii Europejskiej, Warszawa 2010.

Bukowski Z., Wybrane zagadnienia związane z nieprawidłowa implementacja wspólnotowego prawa ochrony środowiska do prawa polskiego, w: J. Jędrośka, M. Bar (red.), Wspólnotowe prawo ochrony środowiska i jego implementacja $w$ Polsce trzy lata po akcesji, Centrum Prawa Ekologicznego, Wrocław 2008.

Bukowski Z. , Zrównoważony rozwój w systemie prawa, Toruń 2009.

Ciechanowicz-McLean J., Penalizacja prawa ochrony środowiska, „Gdańskie Studia Prawnicze”, t. 19, 2008.

Ciechanowicz-McLean J., Międzynarodowe prawo środowiska wobec problemów globalnych, "Gdańskie Studia Prawnicze", t. 17, 2007.

Ciechanowicz-McLean J., Bukowski Z., Rakoczy B., Prawo ochrony środowiska - komentarz, Warszawa 2008.

Ciechanowicz-Mc Lean J. (red)., K. Biernat, P. Mierzejewski, D. Trzcińska, Polskie prawo ochrony przyrody, Warszawa 2006.

Dąbrowska-Kłosińska P., Skutki wyroków prejudycjalnych TS w postępowaniu przed sądami krajowymi $w$ świetle orzecznictwa $i$ Traktatu z Lizbony, „Europejski Przegląd Sądowy” 2010, nr 12.

Di Plinio G., La CITES al vaglio della Corte: la disciplina degli esemplari in cattività di specie minacciate di estinzione tra protezionismo francese, diritto comunitario ambientale e principio di libertà di 
circolazione delle merci, Diritto Pubblico Comparato ed Europeo 2002.

Erechemla A., Strategia ochrony bioróżnorodności - instrumenty prawne, „Prawo i Środowisko”, 30 czerwca 2012 r., nr 2 (70)11.

Faure M.G., Svatikova K., Criminal or Administrative Law to Protect the Environment? Evidence from Western Europe, Oxford Journals, „Journals of Environmental Law” 2012, nr 24(2).

Fischer K. H., Naturschutz, w: Österreich und das Umweltrecht der Europäischen Union, Wien Ueberreiter 1996.

Fuchs Ch., Convention on International Trade in Endangered Species of Wild Fauna and Flora (CITES) Conservation Efforts Undermine the Legality Principle, Bogdandy A., Wolfrum R., Bernstorff J., Dann F., Goldmann M. (red.), The Exercise of Public Authority by International Institutions - Advancing International Institutional Law, Max Plank Institut für ausländisches Rechts und Völkerrechts, Springer 2010.

Gardjan-Kawa L., Zarys ewolucji prawa ochrony przyrody $i$ środowiska $w$ aspekcie międzynarodowym i $w$ Polsce, "Rzeszowskie Zeszyty Naukowe" 1999, nr 27.

Gardocki L., Prawo karne-podręcznik prawnicze, Warszawa 2011.

Godek A., Zastosowanie derywacyjnej koncepcji wykładni prawa do rozstrzygania spraw ze stosowaniem przepisów unijnych, „Ruch Prawniczy Ekonomiczny i Socjologiczny", Poznań 2011, nr 1.

Gruszecki K., „Ustawa o ochronie przyrody. Komentarz”, Warszawa 2010.

Grzelak A., Królikowski M., Sakowicz A. (red.), Europejskie prawo karne, Warszawa 2012.

Grzybowski T., Spory wokót reguty clara non sunt interpretanda, " Państwo i Prawo" Warszawa 2012, nr 9.

Górski M. (red.), Kierzkowska J. S., Prawo ochrony środowiska, Bydgoszcz 2006.

Górski M., Ochrona środowiska jako zadanie administracji publiczne, Łódź 1992.

Górski M., Gospodarowanie odpadami w świetle wymagań prawa wspólnotowego i polskiego prawa wewnętrznego, Poznań 2005.

Górski M., Prawo międzynarodowe a ochrona warstwy ozonowej, „Studia Prawno-Ekonomiczne" 1997, t. 55.

Górski M., Odpowiedzialność administracyjnoprawna w ochronie środowiska, Warszawa 2008.

Górska M.A., Legat A., Stosowanie przepisów rozporządzeń wspólnotowych $w$ świetle orzecznictwa Naczelnego Sądu Administracyjnego, „Przegląd Sądowy” 2009, nr 7-8. 
Gwiazdowicz M., System ochrony przyrody w Polsce - regulacje prawne $i$ instytucje. Problemy systemu ochrony przyrody, w: E. Karpowicz (red.), Ochrona przyrody, Studia Biura Analiz Sejmowych Kancelarii Sejmu, Warszawa 2008.

Iwanek-Chachaj E., Zasada prewencji i przezorności w prawie ochrony środowiska, " Studia Iuridica Lublinensia", Lublin 2008.

Jacobs F., The Role of the European Court of Justice in the Protection of the Environment, „Oxford Journals, Journals of Environmental Law" 2006, nr 18(2).

Kamiński C.I., Wymiar Sprawiedliwości we Wspólnocie Europejskiej. Praktyczny komentarz i przepisy, Warszawa 2004.

Kastelik-Smaza A., Pytanie prejudycjalne do Trybunału Sprawiedliwości Unii Europejskiej a ochrona praw jednostki, Warszawa 2010.

Kenig-Witkowska M.,„Międzynarodowe prawo środowisk”, Warszawa 2011.

Kepel A., Pawlaczyk P., Opinia dotycząca projektów ustaw o zmianie ustawy o ochronie przyrody oraz niektórych innych ustaw oraz o udziale społeczeństwa $w$ ochronie środowiska oraz o ocenach oddziaływania na środowisko, w: Kancelaria Sejmu - Biuro Analiz Sejmowych, Zmiany $w$ systemie ochrony środowiska - Druk Sejmowy nr 767, 768, wrzesień 2008, nr 5.

Klenowska K., Zasada suwerenności terytorialnej $w$ ochronie środowiska, „Przegląd Prawa Ochrony Środowiska” 2009, Nr 1.

Koch B., Z problematyki przepisów blankietowych $w$ prawie karnym, „Acta Universitatis Nicolai Copernici”, Prawo, t. 16, 1978.

Koopmans I. M., Strafrechtelijke handhaving van CITES en aanverwante regelgeving in Nederland, w: Koopmans I. M., Verschuuren J. (red.), Handhaving van Europees milieurecht in Nederland, Boom Juridische Uitgevers, 2000.

Kowalik-Bańczyk K., Prowspólnotowa wykładnia prawa polskiego, „Europejski Przegląd Sądowy" 2005, nr 12.

Krawczyk M.,„Ochrona środowiska w regulacji kodeksu karneg”, w:Górski M., Bucińska J., Niedziółka M., Stec R., Strus D. (red.), Administracja publiczna - człowiek a ochrona środowiska. Zagadnienia społeczno-prawne, Warszawa 2011.

Krzysztofiuk G., Obowiązek prounijnej interpretacji prawa karnego, „Studia Iuridica”, t. 46, „Z Zagadnień Prawa Karnego”, Wydawnictwa Uniwersytetu Warszawskiego 2006.

Krzywoń A., Konstytucja RP a środowisko, „Państwo i Prawo” sierpień 2012, nr 8.

Korzeniewski P., Zasady prawne ochrony środowiska, Łódź 2010. 
Kozak A., Pojmowanie prawa w teorii wykładn", Wydawnictwo Uniwersytetu Wrocławskiego 1997, Prawo CCLX.

Kurzępa B., Kotowski W., Wykroczenia pozakodeksowe - Komentarz, Warszawa 2008.

Kustra A., Blankietowość norm prawnokarnych jako problem konstytucyjny, „Forum Prawnicze” 2012, nr. 1.

Łazowski A., Stosowanie rozporządzeń wspólnotowych na płaszczyźnie wewnętrznej państw członkowskich, w: Prawo Unii Europejskiej $w$ wewnętrznym porządku prawnym państw członkowskich, Warszawa 2004.

Łętowska E., Interpretacja a subsumcja zwrotów niedookreślonych i nieostrych, „Państwo i Prawo” 2011, z. 7-8.

Łuczak K., Metody wykładni prawa krajowego, a wykładnia zgodna z prawem unijnym ( $w$ orzecznictwie sądów administracyjnych), „Państwo i Prawo” 2011, z. 1.

Malinowski A. (red.), Logika dla prawników, Warszawa 2010.

Malinowski A., Redagowanie tekstu prawnego. Wybrane wskazania logiczno-językowe, Warszawa 2008.

Mering L., Środowisko, jako przedmiot ochrony karnoprawnej, „Gdańskie Studia Prawnicze", t. 14, 2005.

Michalak M., Rola zasady przezorności ( $w$ definiowaniu pojęć wspólnotowego porządku prawnego $w$ orzecznictwie Europejskiego Trybunału Sprawiedliwości), „Prawo i Środowisko” nr 1(61)/10.

Milke A., Zarys konstytucyjnych podstaw ochrony środowiska, „Studia Iuridica", t. 50 L/2009.

Mik C, Europejskie prawo wspólnotowe - Zagadnienia teorii i praktyk", Warszawa 2000.

Nowacki J., Studia z teorii prawa, Zakamycze 2003.

Piontek E., Doktryna i praktyka „acte clair”, a wspólnotowy porządek prawny $w$ kontekście funkcji art. 234 TWE, w:. Piontek A., Zawadzka E. (red.) Prawo polskie a prawo Unii Europejskiej, Warszawa 2003.

Piontek E., Zasada pierwszeństwa prawa wspólnotowego w orzecznictwie państw członkowskich, „Państwo i Prawo” 2009, nr 5.

Półtorak N., Procedura prejudycjalna - wprowadzenie $i$ wyrok Trybunału z 14.01.1974 r. w sprawie 166/73 Rheinmühlen-Düsseldorf v. Einfuhr- und Vorratsstelle für Getreide und Futtermittel, „Europejski Przegląd Sądowy" 2010, nr 8.

Przyborowska-Klimczak A., Pojęcie różnorodności biologicznej w świetle międzynarodowego prawa ochrony przyrody, „Prawo-Administracja-Kościół” 2000, nr 4. 
Radecki W., Ochrona środowiska w polskim prawie karnym, cz. I: Pojęcie i zakres prawa karnego środowiska, „Monitor Prawniczy” 1997, nr 12.

Radecki W. (red.), Teoretyczne podstawy prawa ochrony przyrody, Towarzystwo Naukowe Prawa Ochrony Środowiska, Seria: Monografie Nr 53.

Radecki W., Prawna ochrona przyrody $w$ Polsce, Czechach i Stowacji: studium porównawczoprawne, Warszawa 2010.

Radecki W., Ustawa o ochronie przyrody. Komentarz, Warszawa 2006.

Radecki W., Odpowiedzialność za wykroczenia jako środek prawny ochrony środowiska, Rakoczy B., Pchałek M. (red.), Wybrane problemy prawa ochrony środowiska, Warszawa 2010.

Radecki W., Wykroczenia i przestępstwa przeciwko środowisku - przewodnik po przepisach, Warszawa-Wrocław 1995.

Radecki W., Interpretacje prawnicze. Państwowa Rada Ochrony Przyrody, „Ochrona Środowiska” 2007, nr 3.

Rakoczy B., Ograniczenie praw i wolności jednostki ze względu na ochronę środowiska w Konstytucji Rzeczypospolitej Polskiej, Toruń 2006.

Rigaux A., Compétence de la Cour et recevabilité des questions préjudicielles, „Europe” 2012, Août Septembre Comm., nr 8-9.

Roliński M., Ewolucja pojęcia prawnego „środowisko” $i$ „ochrona środowiska”, „Studia Iuridica Lublinensia”, Lublin 2005.

Skarżyńska W., Bojarski M., Bar M., Boć J., Nowacki K., Jerzmański J., Górski M., Jendrośka J. (red. nauk.), Kaleta-Jagiełło E, Rotko J., Tatomir T., Lipiński A., Ustawa - Prawo ochrony środowiska. Komentarz, Centrum Prawa Ekologicznego, Wrocław 2001.

Stępień M., Rejestrowanie zwierząt i roślin podlegających ograniczeniom na podstawie konwencji waszyngtońskiej, „Prawo i Środowisko” 2004, nr 1.

Solon J., O potrzebie rewolucyjnych zmian $w$ prawie ochrony przyrody, w: D. Kopeć, N. Ratajczak (red.), Prawo ochrony przyrody - stan obecny, problemy, perspektywy, Towarzystwo Przyrodników Ziemi Łódzkiej, Łódź 2008

Stefanicki R., Fundamenty efektywności prawa wspólnotowego, „Studia Prawnicze" 2004, nr 3.

Szwarc-Kuczer M., Ochrona praw jednostek $w$ dziedzinie wspótpracy sadowej w prawach karnych, w: Wróbel A. (red.), Karta Praw Podstawowych $w$ europejskim i krajowym porzadku prawnym, Warszawa 2009.

Świecki D., Apelacja w postępowaniu karnym, Warszawa 2012.

Taborowski M., Konsekwencje naruszenia prawa Unii Europejskiej przez sacdy krajowe Warszawa 2012. 
Talaga R., Pytania prejudycjalne do Trybunatu Sprawiedliwości UE $w$ praktyce polskich sądów administracyjnych, „Studia Europejskie", Warszawa 2010.

Trych T., Tożsamość oskarżonego bez ochrony, „Dziennik Gazeta Prawna B", 16.07.2012, nr 136.

Wasilewski T., Stosunek wzajemny: porządek międzynarodowy, prawo międzynarodowe, europejskie prawo wspólnotowe, prawo krajowe, Toruń 2004.

Wijnstekers W., The Evolution on of CITES, International Council for Game and Wildlife Conservation, 9th edition on 2011.

Woźnika M., Aspekty stosowania umów międzynarodowych przez organy administracji na przykładzie prawa ochrony środowiska, B. Banaszak (red.), „Przegląd Prawa i Administracji Tom LIV”, Wrocław 2003.

Wróblewski J., Zagadnienie teorii wykładni prawa ludowego, Warszawa 1959.

Wyrembak J., Zasada nulla crimen sine lege a wyktadnia prawa (ze szczególnym uwzględnieniem pozycji metody językowej), „Przegląd Sądowy", styczeń 2009.

Wyrembak J., Wattpliwości co do sposobu rozumienia ustawy karnej jako podstawa jej zasadniczej wykładni, „Studia Iuridica”, t. 46, Z Zagadnień Prawa Karnego, Wydawnictwa Uniwersytetu Warszawskiego 2006.

Zieliński M., O pojęciu międzynarodowego prawa administracyjnego, „Państwo i Prawo” 2008, z. 9.

Zieliński M., Wykładnia prawa. Zasady, reguły, wskazówki, Warszawa 2008.

Ziembiński Z., Logika praktyczna", w: Wydawnictwo Naukowe PWN Warszawa 2009.

Ziembiński Z., „Podstawy sporu o luki w prawie, „Państwo i Prawo” 1966, nr 2.

Zięba J., Instytucja orzeczeń wstępnych Trybunału Wspólnot Europejskich, „Studia Prawnicze” 2004, nr 4.

Kontakt e-mail:

piterecki@poczta.onet.pl 